\title{
fedea
}

\section{Household Debt and Fiscal Multipliers}

\author{
by \\ J. Andrés* \\ J.E. Boscá ${ }^{*}$ \\ J. Ferri ${ }^{* *}$ \\ Documento de Trabajo 2015-01
}

March 2015

* University of Valencia.

** University of Valencia and FEDEA

Los Documentos de Trabajo se distribuyen gratuitamente a las Universidades e Instituciones de Investigación que lo solicitan. No obstante están disponibles en texto completo a través de Internet: $h t t p: / / w w w$.fedea.es.

These Working Paper are distributed free of charge to University Department and other Research Centres. They are also available through Internet: http://www.fedea.es.

ISSN:1696-750 


\title{
Household Debt and Fiscal Multipliers*
}

\author{
J. Andrés (University of Valencia) \\ J.E. Boscá (University of Valencia and FEDEA) \\ J. Ferri (University of Valencia and FEDEA)
}

February, 2015.

\begin{abstract}
We study the size of government spending multipliers in a general equilibrium model with search and matching frictions in which we allow for different levels of household indebtedness. The main results of the paper are: (a) the presence of impatient households and private debt helps generate government spending multipliers greater than 1 ; (b) as financial conditions worsen and impatient consumers find it more difficult to borrow (i.e. in a credit crunch), the size of the government spending multiplier falls; (c) conversely, employment, vacancies and unemployment multipliers are larger when access to credit becomes more difficult; and (d) the model explains the observed pattern of responses of labour market variables, housing prices and private debt to a fiscal shock reasonably well. On these grounds it outperforms the standard model with Rule-of-Thumb consumers whose predictions for the labour market are at odds with the data.
\end{abstract}

Keywords: fiscal multipliers, private leverage, labour market search.

JEL Classification: E24, E44, E62.

\footnotetext{
* We are grateful to seminar participants at the ECB, the University of Glasgow and the University of Kent. Also to attenders to the 27th Annual Congress of the European Economic Association, the 2012 Annual Conference of the Royal Economic Society, the 17th World Congress of the International Economic Association, the Banque de France, Euro Area Business Cycle Network and the Paris School of Economics conference Fiscal and Monetary Policy in the Aftermath of the Financial Crisis (Paris, 2011) and the $I_{t}$ Workshop in Time Series Econometrics (Zaragoza, 2011). Financial support from Fundación Rafael del Pino, BBVAResearch and CICYT Grant ECO201129050 is kindly acknowledged. Part of this research was conducted while Boscá was visiting the School of Economics at University of Kent and Ferri the Business School at the University of Glasgow. The hospitality of these institutions is greatly appreciated. This paper has been previously circulated with the title "Household Leverage and Fiscal Multipliers. All remaining errors are our own responsibility.
} 


\section{Household Debt and Fiscal Multipliers}

J. Andrés, University of Valencia

J.E. Boscá, University of Valencia and FEDEA

J. Ferri, University of Valencia and FEDEA

In this paper we analyse the effect of household leverage in the response of macroeconomic variables to a government spending shock. Our work is motivated by two facts. First, the discussion on the output and employment effects of government spending stimuli -and the reaction of the economy to their withdrawal- which has been central to the political and academic debate over the last few years. Second, the rise in private debt, which has been one of the most important developments in the run-up to the financial crisis. According to the IMF's 2012 World Economic Outlook, the ratio of household debt to income rose by an average of 39 percentage points to 138 percent in advanced economies over the five-year period preceding 2007. Thus, the current financial crisis has caught most firms and households in a highly leveraged position with mortgages and other loans, after many years of financial deepening linked to the growing demand for housing.

The main results of the paper can be summarised as follows. First, in line with the results of Eggertsson and Krugman (2012), we find that the presence of borrowing constraints and household indebtedness increases the value of the multiplier as compared with a model in which there is no private debt. Second, as financial conditions worsen and impatient consumers find it more difficult to borrow (i.e. in a credit crunch) the size of the government spending multiplier falls. These results can be read in two ways regarding the current policy debate. When debt levels are high due to easy access to credit, fiscal multipliers are expected to be large. However, fiscal expansions might lose strength after a credit crunch because constrained consumers find it more difficult to borrow. Third, although output multipliers fall as financial conditions tighten, (un)employment multipliers increase. In economies in which credit is scarce, the increase in negotiated wages after the fiscal expansion is more moderate. This makes posting new vacancies a more appealing option for firms so the increase in total working hours takes place mostly through new jobs. Fourth, the model explains the observed pattern of responses of labour market variables, housing prices and private debt to a fiscal shock reasonably well. On these grounds it outperforms the standard model with RoT households, which produces an even larger fiscal multiplier, but whose predictions for the labour market are at odds with the data. In the RoT model, the sharp increase in consumption pushes up negotiated wages so strongly that firms are less inclined to post new vacancies and prefer to exploit the intensive margin instead, causing a reduction in total employment. 


\section{Introduction}

In this paper we analyse the effect of household leverage in the response of macroeconomic variables to a government spending shock. Our work is motivated by two facts. First, the discussion on the output and employment effects of government spending stimuli -and the reaction of the economy to their withdrawal- which has been central to the political and academic debate over the last few years. Examples include Romer and Bernstein (2009), Cogan et al. (2010) and Uhlig (2010), regarding the expected impact of the US fiscal packages. Second, the rise in private debt, which has been one of the most important developments in the run-up to the financial crisis. According to the IMF's 2012 World Economic Outlook, the ratio of household debt to income rose by an average of 39 percentage points to 138 percent in advanced economies over the five-year period preceding 2007. Thus, the current financial crisis has caught most firms and households in a highly leveraged position with mortgages and other loans, after many years of financial deepening linked to the growing demand for housing.

Some recent papers have pointed out the linkage between the presence of strongly debt-constrained agents and economic activity in the present slump. The IMF has shown that consumption and employment have fallen more in countries where the household debt to disposable income ratio was higher before the crisis (see Figure 2 in IMF WEO, 2012). Mian and Sufi (2010) exploit county-level data for the US and find clear correlation between the growth in household leverage from 2002 to 2006, the fall in house prices and the rise in unemployment after the crisis. Glick and Lansing (2010) show that the countries that experienced the largest declines in household consumption after the financial crisis were those that prior to 2007 witnessed the highest increases in house prices and household leverage. In a fully specified dynamic model, Hall (2011) studies the response of output and unemployment when the economy is hit by adverse forces related to the stock of housing, the number of liquidity constrained households and the degree of financial frictions. Also, Monacelli et al (2011) have shown that credit shocks can generate large and persistent (un)employment fluctuations, their mechanism operating through firms' incentive to borrow in order to affect wage bargaining.

However, despite the role of private leverage in the current economic crisis, household debt has usually been absent from the theoretical analysis of fiscal policy ${ }^{1}$. Most fiscal multiplier models were populated either by Ricardian consumers or by households without access to financial markets. These are two extreme cases as far as the composition of the balance sheet of households is concerned: while Ricardian consumers hold assets

1 A non-exhaustive list of exceptions includes Callegari (2007), Roeger and int Veld (2009), Eggertsson and Krugman (2012) and Guerrieri and Lorenzoni (2011). Other approaches connect fiscal policy and financial frictions through the effect on the financial premium paid by firms (see Fernández-Villaverde, 2010 and Carrillo and Poilly, 2010). 
but have no debt, the so called Rule-of-Thumb (RoT) or hand-to-mouth consumers do not save or borrow and, hence, have neither assets nor liabilities. Ricardian household consumption is driven by expected lifetime income, which might be negatively affected by a fiscal expansion through several channels, such as an interest rate rise, a fall in asset prices, or a fiscal expansion reversal, whereas RoT consumption depends only on current labour income, which increases after public spending rises.

But many households not only have assets, but also liabilities, so their consumption decisions are affected by the evolution of their net worth, including real estate and private debt. In this paper we study the size of fiscal multipliers, paying special attention to the main determinants of consumption, labour income and net worth and we augment the canonical Neo-Keynesian model in two directions to that end. We include financial frictions drawing on Iacoviello (2005). All agents in the economy participate in the financial market, but due to differences in their subjective valuation of the future, the most impatient of them borrow from the patient ones. The amount of borrowing is limited by the value of the collateral given by the expected value of the household's housing holding. Hence, even constrained consumers are somehow engaged in intertemporal substitution, such that a modified version of the Euler condition on consumption still prevails. Also, as the labour market dynamics is essential in the transmission of fiscal impulses, we allow for two-sided market power, wage bargaining and matching frictions à la Mortensen and Pissarides (1994). Hence, we take up the challenge launched by Pissarides (2011) of integrating the financial sector and the labour market.

Our work relates to Eggertsson and Krugman (2012), who include debt in a macro model and find that the presence of constrained borrowers strengthens the effect of fiscal policy. The presence of debt, which households must service, opens up a channel through which fiscal stimuli might have a strong marginal effect on consumption. An increase in public spending pushes up labour income and reduces the real value of debt through inflation, leading to a strong response of consumption.

We develop this set-up by considering that household borrowing is endogenous and most importantly that a great proportion of it is not devoted to current consumption, but rather to purchase a particular asset: housing. In most advanced economies, including the US and the European Union, mortgages reached around $80 \%$ of total household borrowing before the crisis, which is of great significance for the analysis of consumption decisions, as the value of housing is a key determinant of net worth. In the presence of collateral requirements, the predominance of housing in borrowing has additional implications for consumption. While higher housing prices during the boom expanded available collateral, their continuous decline during the deleveraging period may have aggravated the credit 
crunch by further depressing private spending ${ }^{2}$.

Regarding the analysis of fiscal policy, the presence of leveraged asset holders creates a new channel through which government spending may influence consumption. Lending contracts are usually expressed in nominal terms and, thus, a fiscal stimulus that raises inflation erodes the real value of outstanding debt with a positive effect on consumption. However, both borrowers and also lenders possess assets (housing), the price of which might also be negatively affected by a fiscal expansion (an effect that was already pointed out by Matsuyama, 1990). Thus, the net worth of borrowers suffers two opposite effects after a fiscal expansion that, in conjunction with the response of labour income, determine the size of the multiplier. The importance of household's mortgages and collateralized assets to frame the effects of fiscal policy has also been discussed by Cloyne and Surico (2014), who find that households with mortgage debt exhibit a large response of consumption to changes in income taxes. Similarly, Kaplan, Violante and Weidner (2014) find that wealthy hand-to-mouth households (i.e. households with little or no liquid wealth but with a sizable amount of illiquid assets, such as houses) display a high propensity to consume out of transitory income changes.

The main results of the paper can be summarised as follows. First, in line with the results of Eggertsson and Krugman (2012), we find that the presence of borrowing constraints and household indebtedness increases the value of the multiplier as compared with a model in which there is no private debt.

Second, as financial conditions worsen and impatient consumers find it more difficult to borrow (i.e. in a credit crunch) the size of the government spending multiplier falls. These results can be read in two ways regarding the current policy debate. When debt levels are high due to easy access to credit, fiscal multipliers are expected to be large. However, fiscal expansions might lose strength after a credit crunch because constrained consumers find it more difficult to borrow. In other words, it is not the level of debt, but the (marginal) access to new credit that tends to augment the multiplier. Brückner and Tuladhar (2014) present empirical evidence in line with this result and find that firms' financial distress has a significant negative effect on the government spending multiplier, in contrast to economic slack that has a significant positive effect.

Third, although output multipliers fall as financial conditions tighten, (un)employment multipliers increase. In economies in which credit is scarce, the increase in negotiated wages after the fiscal expansion is more moderate ${ }^{3}$. This makes posting new vacancies a

2 Adam et al. (2011) develop a model to show the connection between housing prices, consumption and the current account.

3 This result is akin to that of Monacelli et al. (2011) although the economic rationale is different. In our case, credit shortages trigger a strong reaction of the marginal utility of consumption that weakens the relative 
more appealing option for firms so the increase in total working hours takes place mostly through new jobs.

Fourth, the model explains the observed pattern of responses of labour market variables, housing prices and private debt to a fiscal shock reasonably well. On these grounds it outperforms the standard model with RoT households, which produces an even larger fiscal multiplier, but whose predictions for the labour market are at odds with the data. In the RoT model, the sharp increase in consumption pushes up negotiated wages so strongly that firms are less inclined to post new vacancies and prefer to exploit the intensive margin instead, causing a reduction in total employment.

The paper is organised as follows. Section 2 presents the results from the VAR analysis and relates them to other empirical evidence. Section 3 summarises the baseline model with borrowers and lenders in a search and matching framework. Section 4 introduces the results. We begin by comparing the impulse response functions to a government spending shock in models with and without borrowing constraints. Then, we present our core results by computing the value of the multipliers when private leverage varies in the economy. Finally, we discuss the different reactions of variables in a model of financially constrained consumers with neither assets nor liabilities (hand-to-mouth consumers) and establish the differences with respect to our baseline model. Section 5 concludes.

\section{Empirical evidence}

In this section we first present an abridged overview of the empirical evidence regarding the effects of government spending shocks, more specifically those most closely related to our model below. Next, we perform our own VAR analysis including the variables that play a key role in the transmission mechanism in our theoretical model.

The empirical analysis of the fiscal multiplier gathered momentum after the work of Blanchard and Perotti (2002), who estimated a VAR for the US economy with a careful identification approach to the effect of discretionary fiscal policy changes. They found that, consistent with a Keynesian view, output and consumption increase in response to a positive government spending shock. These results are in line with those obtained in Burnside et al. (2004), Fatás and Mihov (2001) and Galí et al. (2007), among others. In contrast with these results, another stream of the literature has found that fiscal policy may have non-Keynesian effects. Beginning with the work of Giavazzi and Pagano (1990), many studies have analysed the macroeconomic effect of fiscal consolidations. In their survey of this literature, Hemming et al. (2002) conclude that there are many examples in 
which fiscal contractions have had expansionary effects on output, private consumption and investment.

The financial crisis has aroused renewed interest in the effects of fiscal policy as the debate involving Romer and Bernstein (2009), Cogan et al. (2010), Uhlig (2010) and Taylor (2011) demonstrates. There is now widespread consensus about the importance of the monetary policy reaction to fiscal shocks as a major determinant of the size of the multipliers as Woodford (2011) emphasises. These multipliers become unusually large if the economy hits the zero bound of the nominal interest rate, as shown by Christiano et al $(2011)^{4}$.

According to Ramey's recent review of the literature (Ramey, 2011a), the theoretical work on government spending yields a wide range of possible values for the multiplier, depending on the assumptions in each model, the way monetary policy reacts or how government spending is financed and its degree of persistence. However, looking at the empirical work, Ramey concludes that "...despite significant differences in methodology, the range of plausible estimates for the multiplier in the case of a temporary increase in government spending that is deficit financed is probably 0.8 to 1.5 " although "...reasonable people could argue that the multiplier is 0.5 or 2.0 without being contradicted by the data". Also, in their empirical survey, Spilimbergo et al. (2009) conclude that "the size of the fiscal multiplier is country-, time-, and circumstance-specific".

In any case, most of the empirical work tends to favour the view that government spending multipliers are positive, although there is still no agreement regarding the mechanism by which the rise in GDP takes place. More specifically, in neoclassical models where consumers fully optimise intertemporally, increases in government spending lead to a decline in consumption, while in models populated with rule-of-thumb consumers the opposite is true. Galí et al. (2007) summarise the empirical evidence to this respect and conclude that none of the evidence appears to support the kind of strong negative comovement between output and consumption predicted by the neoclassical model in response to changes in government spending. The bulk of empirical papers focusing on the response to changes in government spending tend to support the traditional Keynesian hypothesis that consumption expenditure rises after a positive government spending shock. From a more microeconomic point of view, recently Parker et al (2011) and Misra and Surico (2011) also find a significant positive response of consumption to government payments.

The ultimate effects of fiscal expansions on the economy crucially depend on the reaction of employment. Despite this circumstance, the response of labour market variables to fiscal shocks has received less attention in the literature. However, the empirical liter-

4 In contrast, Alesina and Ardagna (2010) argue that fiscal contractions might even be expansionary under fairly general conditions. 
ature on this issue points towards a government spending shock having a positive effect on vacancies and employment and a negative effect on unemployment (see Monacelli et al, 2010, and Ravn and Simonelli, 2008). Brückner and Pappa (2010) find a positive effect on employment, although the unemployment rate may not fall due to an increase in the participation rate.

As regards the role of financial conditions, recent literature points towards the importance of the reaction of asset prices as a transmission mechanism in the final value of the multiplier, something that will be of key importance in our theoretical analysis. In particular, some empirical studies find that a positive government consumption shock generates a reduction in housing and other asset prices. Ardagna (2009), using a panel of OECD countries, shows that stock market prices surge around times of substantial fiscal tightening and plunge in periods of very loose fiscal policy. Similarly, Agnello and Sousa (2011 and 2012) produce robust evidence, using a panel vector auto-regressive (PVAR) approach for ten industrialised countries, that positive fiscal shocks lead to a temporary fall in stock prices and a gradual and persistent decrease in housing prices.

Most of the papers mentioned so far look at the interaction among a subset of the variables we are interested in. We next use a unified VAR framework that looks at all the relevant variables in our model: output, consumption, labour market aggregates, housing prices and household debt. Following Fatás and Mihov (2001) and Blanchard and Perotti (2002), the identification scheme assumes that government spending is predetermined and does not react to other shocks in the model within the same quarter. Thus, we use a Choleski decomposition and place government spending as the first variable.

We follow a model strategy akin to Monacelli et al. (2010). We estimate a set of seven-variables VARs that include a fixed set of five variables to which we add different pairs in turn. The common set of variables are the following: the log of real per-capita government consumption, the log of real per-capita GDP, the log of real per-capita private consumption (of non durables and services), the nominal interest rate on 3-month T-bills and the log of real per-capita government tax revenues (tax receipts less current transfers, interest payments and subsidies). All data series are taken from FRED, except government consumption and tax revenues, which come from BEA. Our sample covers the period 1964:1-2007:4. It starts in 1964, conditioned by the availability of housing prices. The end date avoids using data of the Great Recession period, during which the multiplier might be largely driven by the zero lower bound, a fact from which we abstract later in our theoretical analysis. All our specifications include four lags for the endogenous variables, a constant, a time trend and a quadratic time trend. We construct three dummies taking values of one for the three "Ramey-Shapiro" war dates in our sample, i.e 1965:1, 1980:1 and 2001:3 (see Ramey and Shapiro, 1998 and Ramey, 2011b), and then include lags 0-4 of these 
dummies as exogenous variables in the VAR. This approach is also used by Monacelli et al. (2010), Rossi and Zubairy (2011) and Corsetti et al (2012) as a way to control for anticipated changes in government spending.

In the first specification we add the log of per-capita total employment and the log of per-capita total weekly hours to the fixed set of variables. Figure 1 displays the responses ${ }^{5}$ to a one-percentage point of GDP shock in government spending of: total tax revenues, private consumption, GDP, as well as government spending itself. The responses of the variables in Figure 1 are normalised as percentage points of GDP. The government spending shock increases consumption and GDP on impact, implying an impact GDP multiplier of 1.08. The effect of the shock is very persistent and both consumption and GDP peak after two years. The estimated cumulative output multipliers are 1.38 for the first year and 1.89 over a two-year horizon. Interestingly, we also find a significant rise in tax revenues that reaches the same magnitude as the initial increase in government spending after two years. The responses of employment and hours can be found in the first column of Figure 2. Employment rises with a peak response of about $1.5 \%$ after ten quarters, whereas hours significantly peak at about $3 \%$ after two years. This implies a rise in hours per worker of around $1.5 \%$ between the eighth and the tenth period.

In the next specification we add the log of per-capita total unemployment and the $\log$ of per-capita vacancies ${ }^{6}$. Results are in column 2 of Figure 2. Unemployment experiences a significant and persistent fall, peaking at about 18 percentage points after nine quarters. Vacancies also increase persistently, reaching a peak of near 15 percent after eight quarters.

Next, we include the log of real hourly earnings (as a measure of wages) and the log of per-capita civilian labour force. Wages increase by about 2 percentage points after two years, whereas the labour force displays very persistent behaviour, increasing slowly and peaking after the third year (third column of Figure 2).

Overall, our results for the different VAR specifications that include labour market variables confirm the results of Monacelli et al (2010). However, we are primarily interested in the response of housing prices and household debt to the fiscal shock. To this end we add housing prices (constructed as a Fisher index) and outstanding household debt in the form of mortgages, to the common set of variables. In order to check the robustness of results to the definition of the variables, we also consider an alternative pair of variables: a Laspeyres housing price index and the household credit market debt outstanding. Results

\footnotetext{
5 Responses are averages derived from 1000 Monte Carlo replications and are accompanied by one standard error confidence bands.

6 We use the Conference Board help-wanted advertising index, which ends in 2006. Thus, we extrapolate to 2012 using the series from the online help-wanted advertising index that starts in 2005.
} 

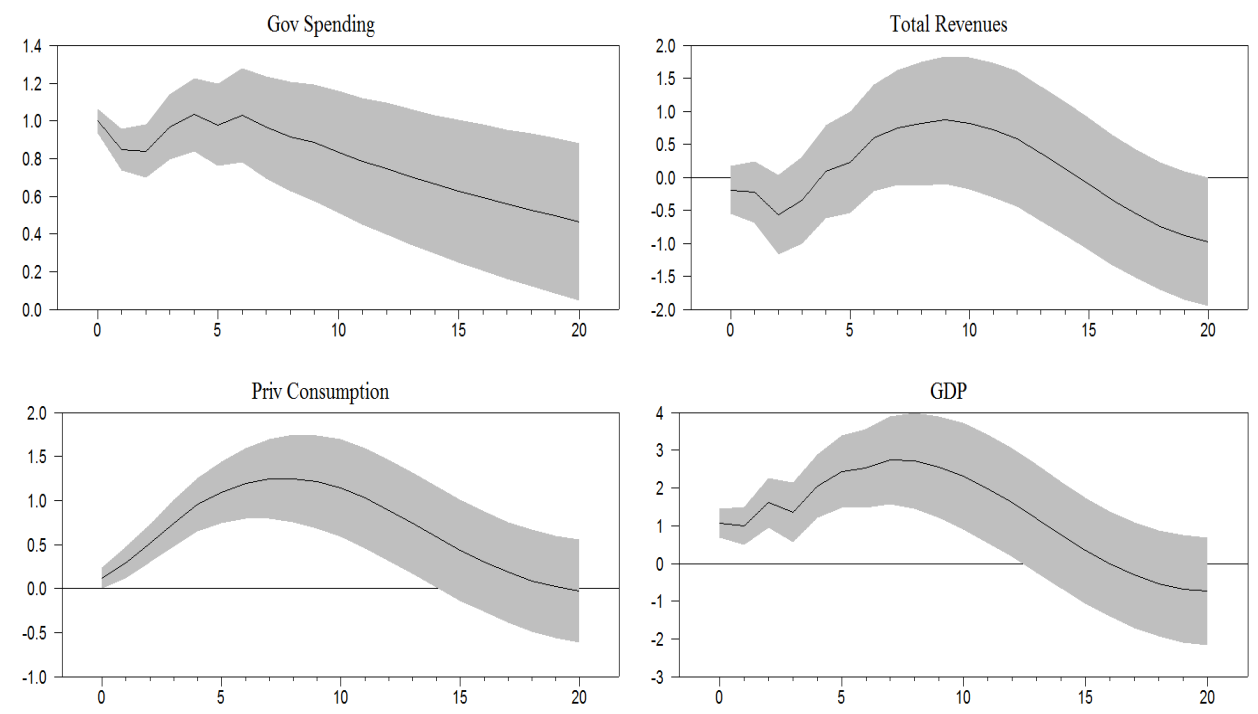

Figure 1: Impulse responses to a 1\% of GDP increase in government spending. 

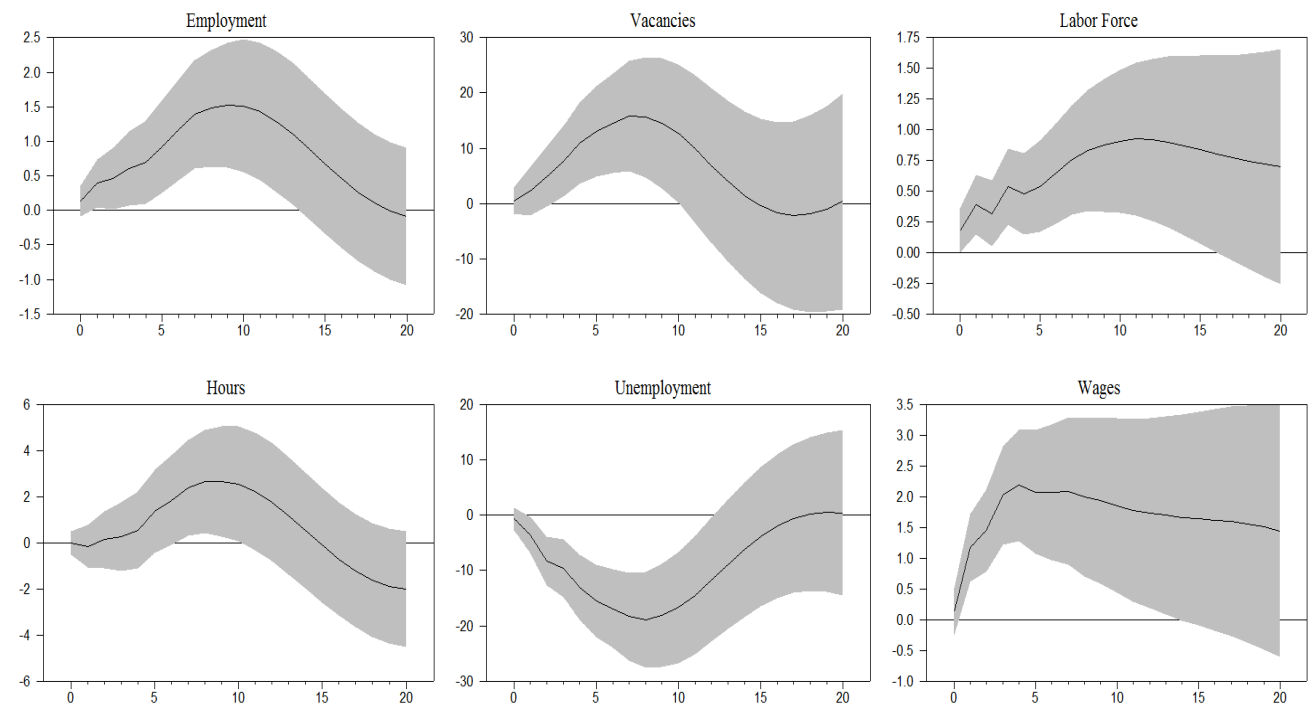

Figure 2: Impulse responses to a 1\% of GDP increase in government spending. 
are in Figure 3 where, again, the responses of mortgages and household debt are expressed as percentage points of GDP. After a positive government spending shock housing prices fall and private debt increases, regardless of the definition of the variables we use. The decrease in housing prices is more intense when prices are measured by a quality constant Laspeyres index (about 3.2 percentage points after one year), but lasts longer when a Fisher index of housing prices is used (after nine quarters the fall in housing prices is still significant). According to the first row in Figure 3 the fiscal shock provokes a marked reaction in household debt (peak multipliers of 3.2 and 2.7 respectively).

Finally, our VAR results have been checked for robustness through additional sensitivity exercises and found them to be fairly robust across different specifications. In particular, we have looked at different dimensions while performing the sensitivity analysis: the change in the number of lags for endogenous variables; the exclusion of the quadratic term from the trend; the change in the number of lags for the war period dummies (results are available upon request). Additionally, in the appendix we provide three other sets of results. First, extending the sample period until 2012:4, second removing the war dummies from the models and, finally, following the approach of Favero and Giavazzi (2012), substituting the nominal interest rate on 3-month T-bills by the ratio of government debt to GDP. The only noticeable difference with the benchmark specification results affects the dynamics of the labour force when the sample period is extended to 2012:4.

\section{The model}

We model a decentralised closed economy in which households and firms trade one final good and two factors of production: productive capital and labour. Besides labour and capital, households own all the firms operating in the economy. Households rent capital and labour services to firms and receive income in the form of interest and wages. While capital is exchanged in a perfectly competitive market, the labour market is non-Walrasian. Firms post new vacancies every period, paying a fixed cost while the vacancy remains unfilled. The fact that trade in the labour market is costly in terms of resources and time generates a monopoly rent associated with each job match. It is assumed that workers and firms bargain over these rents in Nash fashion. Each household is made up of working-age agents who may be either employed or unemployed. If unemployed, agents are actively searching for a job. Firm investment in vacant posts is endogenously determined and so are job inflows. Job destruction is considered exogenous. The policy instruments of the public sector are characterised by a standard interest rate rule and a fiscal rule in lumpsum transfers.

The model goes one step beyond Mankiw's model of savers and spenders (Mankiw, 2000). As in Kiyotaki and Moore (1997), Iacoviello (2005), Monacelli (2009) and Andrés 

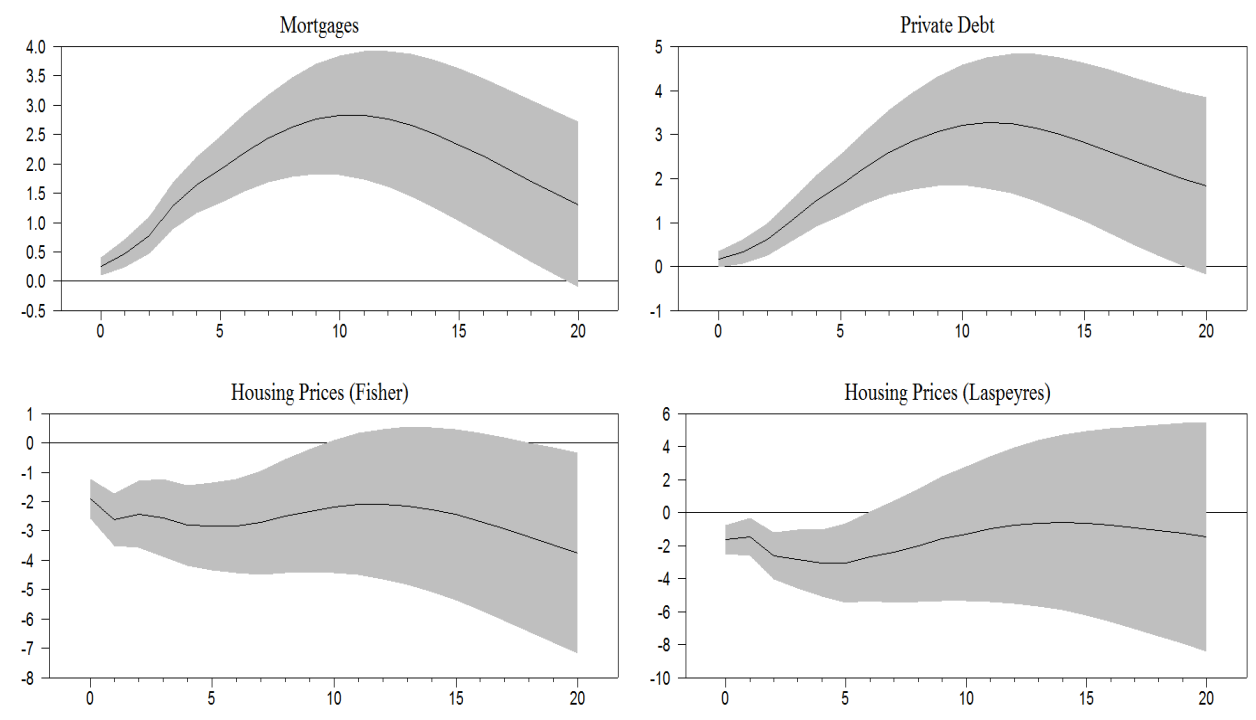

Figure 3: Impulse responses to a $1 \%$ of GDP increase in government spending.

and Arce (2012), there are two types of representative households, $N_{t}^{l}$ of them are patient and $N_{t}^{b}$ are impatient. All have access to financial markets and patient households are characterised by having a lower discount rate than impatient ones; under fairly general conditions patient households are net lenders and owners of physical capital, while impatient households are net borrowers. Due to underlying friction in the financial market, borrowers face a binding constraint in the amount of credit they can take. The size of the working-age population is given by $N_{t}=N_{t}^{l}+N_{t}^{b}$. Let $1-\tau^{b}$ and $\tau^{b}$ denote the proportions of lenders and borrowers in the working-age population; these shares are assumed to be constant over time, unless otherwise stated. Both types of households delegate the bargaining process with firms to a trade union, as in Boscá et al. (2011). We assume no growth in the working-age population.

In our setting fiscal multipliers are affected by both financial frictions and labour market frictions, and both types of frictions interact. The share of impatient households in total population and the propensity to borrow exert a direct effect on wage bargaining and on labour market outcomes. As an example, unlike what happens to patient households, an expansionary fiscal shock has a positive effect on borrowers' consumption thus diminishing their marginal utility of further consumption. This pushes the implicit bargaining 
power in wage negotiations upwards, inducing an even stronger response of wages and aggregate consumption.

Our labour market framework allows us to isolate the response of the intensive and extensive labour margins. Specifically the presence of financial indicators in the bargaining process amplifies the differential response among these two margins as the level of household debt increases. This in turn generates a very different pattern of output and (un)employment multipliers associated with financial deepening.

\subsection{Patient households}

The representative patient household maximises lifetime utility,

$$
\max _{c_{t}^{l}, k_{t}^{l}, j_{t}^{l}, b_{t}^{l}, x_{t}^{l}} E_{t} \sum_{t=0}^{\infty}\left(\beta^{l}\right)^{t}\left[\begin{array}{c}
\ln \left(c_{t}^{l}\right) \\
+\phi_{x} \ln \left(x_{t}^{l}\right)+n_{t-1}^{l} \phi_{1} \frac{\left(1-l_{1 t}\right)^{1-\eta}}{1-\eta} \\
+\left(1-n_{t-1}^{l}\right) \phi_{2} \frac{\left(1-l_{2}\right)^{1-\eta}}{1-\eta}
\end{array}\right]
$$

subject to

$$
\begin{gathered}
c_{t}^{l}+j_{t}^{l}\left(1+\frac{\phi}{2}\left(\frac{j_{t}^{l}}{k_{t-1}^{l}}\right)\right)+q_{t}\left(x_{t}^{l}-x_{t-1}^{l}\right)-b_{t}^{l}-b_{t}^{p}= \\
w_{t} l_{1} n_{t-1}^{l}+r_{t} k_{t-1}^{l}+d_{t}^{l}-\left(1+r_{t-1}^{n}\right)\left(\frac{b_{t-1}^{l}}{1+\pi_{t}}+\frac{b_{t-1}^{p}}{1+\pi_{t}}\right)+t r h_{t}^{l} \\
k_{t}^{l}=j_{t}^{l}+(1-\delta) k_{t-1}^{l} \\
n_{t}^{l}=(1-\sigma) n_{t-1}^{l}+\rho_{t}^{w}\left(1-n_{t-1}^{l}\right)
\end{gathered}
$$

Lower case variables in the maximization problem are normalized by the within group working-age population $\left(N_{t}^{l}\right)$. In our notation, variables and parameters indexed by $b$ and $l$ denote, respectively, impatient and patient households. Non-indexed variables apply indistinctly to both types of households. Thus $c_{t}^{l}, x_{t}^{l}, n_{t-1}^{l}$ and $\left(1-n_{t-1}^{l}\right)$ represent consumption, housing holdings, the employment rate and the unemployment rate of patient households. $l_{1 t}$ and $l_{2}$ are hours worked per employee and hours devoted to job seeking by the unemployed. The time endowment is normalised to one. As we will explain later firms and unions bargain over $l_{1 t}$ whereas the amount of time devoted to job seeking $\left(l_{2}\right)$ is assumed to be exogenous. Future utility is discounted at a rate of $\beta^{l} \in(0,1)$, the parameter $-\frac{1}{\eta}$ measures the negative of the Frisch elasticity of the labour supply and $\phi_{x}$ is the weight of housing in life-time utility. The subjective value of leisure imputed by workers may 
vary across employment statuses $\left(\phi_{1} \neq \phi_{2}\right)$.

The budget constraint (2) describes the various sources and uses of income. Households earn labour income $w_{t} n_{t-1}^{l} l_{1 t}$, where $w_{t}$ stands for hourly real wages. There are three assets in the economy. First, private physical capital $\left(k_{t}^{l}\right)$ that yields $r_{t-1} k_{t-1}^{l}$, where $r_{t}$ represents the gross return on physical capital. Given that firms make extraordinary profits, we assume that lenders receive these in the form of dividends $d_{t}^{l}$. Second, patient households lend in real terms $-b_{t}^{l}$ (or borrow $b_{t}^{l}$ ) to the private sector and $-b_{t}^{p}$ to the public sector. Debt contracts are set in nominal terms and they earn an amount $-(1+$ $\left.r_{t-1}^{n}\right)\left(\frac{b_{t-1}^{l}}{1+\pi_{t}}+\frac{b_{t-1}^{p}}{1+\pi_{t}}\right)$ from financial asset holdings, where $r_{t-1}^{n}$ is the nominal interest rate on loans between $t-1$ and $t$. Third, there is a fixed amount of real estate in the economy and the term $q_{t}\left(x_{t}^{l}-x_{t-1}^{l}\right)$ denotes housing investment by patient households, where $q_{t}$ is the real housing price. Consumption and investment are respectively given by $c_{t}^{l}$ and $j_{t}^{l}\left(1+\frac{\phi}{2}\left(\frac{j_{t}^{l}}{k_{t-1}}\right)\right)$. Total investment outlays are affected by increasing marginal costs of installation. Households receive (pay) lump sum transfers (taxes) from (to) the government $\left(t r h_{t}^{l}\right)$.

The remaining constraints faced by Ricardian households concern the laws of motion for capital and employment. Each period private capital stock $k_{t-1}^{l}$ depreciates at the exogenous rate $\delta$ and is accumulated through investment $j_{t}^{l}$. Thus, it evolves according to (3).

Employment obeys the law of motion (4), where $n_{t-1}^{l}$ and $\left(1-n_{t-1}^{l}\right)$ respectively denote the fraction of employed and unemployed optimizing workers in the economy at the beginning of period $t$. Each period, jobs are destroyed at the exogenous rate $\sigma$. Likewise, new employment opportunities come at the rate $\rho_{t}^{w}$ that represents the probability that one unemployed worker will find a job, which is taken as exogenous by individual workers but is endogenously determined at aggregate level,

$$
\rho_{t}^{w}\left(1-n_{t-1}\right)=\chi_{1} v_{t}^{\chi_{2}}\left[\left(1-n_{t-1}\right) l_{2}\right]^{1-\chi_{2}}
$$

where $v_{t}$ stands for the number of active vacancies during period $t$.

For later use we define the marginal value of employment for a worker $\left(\lambda_{h t}^{l}\right)$ as,

$$
\lambda_{h t}^{l} \equiv \frac{\partial W_{t}^{l}}{\partial n_{t-1}^{l}}=\lambda_{1 t}^{l} w_{t} l_{1 t}+\left(\phi_{1} \frac{\left(1-l_{1 t}\right)^{1-\eta}}{1-\eta}-\phi_{2} \frac{\left(1-l_{2}\right)^{1-\eta}}{1-\eta}\right)+\left(1-\sigma-\rho_{t}^{w}\right) \beta^{l} E_{t} \frac{\partial W_{t+1}^{l}}{\partial n_{t}}
$$

where $W^{l}\left(\Omega_{t}^{l}\right)$ represents the value function of households' maximum utility. $\lambda_{h t}^{l}$ measures the marginal contribution of a newly created job to the utility of the household. The first term captures the value of the cash-flow generated by the new job in $t$, i.e. the labour 
income measured according to its utility value in terms of consumption $\left(\lambda_{1 t}^{l}\right.$ is the marginal utility of consumption). The second term on the right-hand side of (6) represents the net utility stemming from the newly created job. Finally, the third term represents the "capital value" of an additional employed worker, given that the employment status will persist in the future, conditional to the probability that the new job will not be lost.

\subsection{Impatient households}

Impatient households discount the future more heavily than patient ones, so their discount rate satisfies $\beta^{b}<\beta^{l}$. They do not own physical capital or public debt and face the following maximisation program,

$$
\max _{c_{t}^{b}, b_{t}^{b}, x_{t}^{b}} E_{t} \sum_{t=0}^{\infty}\left(\beta^{b}\right)^{t}\left[\begin{array}{c}
\ln \left(c_{t}^{b}\right) \\
+\phi_{x} \ln \left(x_{t}^{b}\right)+n_{t-1}^{b} \phi_{1} \frac{\left(1-l_{1 t}\right)^{1-\eta}}{1-\eta} \\
+\left(1-n_{t-1}^{b}\right) \phi_{2} \frac{\left(1-l_{2}\right)^{1-\eta}}{1-\eta}
\end{array}\right]
$$

subject to a budget constraint, a law of motion of employment equivalent to (4), and a specific liquidity constraint:

$$
b_{t}^{b} \leq m^{b} E_{t}\left(\frac{q_{t+1}\left(1+\pi_{t+1}\right) x_{t}^{b}}{1+r_{t}^{n}}\right)
$$

The maximum loan that an individual can get is a fraction of the liquidation value of the housing stock held by the representative household; thus $m^{b} \in[0,1]$ in (8) represents the loan-to-value ratio. As shown in Iacoviello (2005), without uncertainty the assumption $\beta^{b}<\beta^{l}$ guarantees that the borrowing constraint holds with equality. The presence of this borrowing constraint implies that impatient households' intertemporal substitution is limited as represented by the corresponding Euler equation in consumption,

$$
\lambda_{1 t}^{b}=\beta^{b} E_{t} \lambda_{1+1}^{b}\left(\frac{1+r_{t}^{n}}{1+\pi_{t+1}}\right)+\mu_{t}^{b}\left(1+r_{t}^{n}\right)
$$

where $\mu_{t}^{b}$ is the Lagrange multiplier of the borrowing constraint.

The marginal value of employment for an impatient household worker $\left(\lambda_{h t}^{b}\right)$ can be obtained as,

$$
\lambda_{h t}^{b} \equiv \frac{\partial W_{t}^{b}}{\partial n_{t-1}^{b}}=\lambda_{1 t}^{b} w_{t} l_{1 t}+\left(\phi_{1} \frac{\left(1-l_{1 t}\right)^{1-\eta}}{1-\eta}-\phi_{2} \frac{\left(1-l_{2}\right)^{1-\eta}}{1-\eta}\right)+\left(1-\sigma-\rho_{t}^{w}\right) \beta^{b} E_{t} \frac{\partial W_{t+1}^{b}}{\partial n_{t}}
$$

where $\lambda_{h t}^{b}$ measures the marginal contribution of a newly created job to the utility of the household and $W^{l}\left(\Omega_{t}^{l}\right)$ can be interpreted in the same way as for patient households. 


\subsection{Production}

The productive sector is organised in three different levels: (1) firms in the wholesale sector use labour and capital to produce a homogenous good that is sold in a competitive flexible price market at a price $P_{t}^{w} ;(2)$ the homogenous good is bought by firms (indexed by $\widetilde{j}$ ) in the intermediate sector and converted, without the use of any other input, into a firmspecific variety that is sold in a monopolistically competitive market, in which prices are sticky; (3) finally there is a competitive retail aggregator that buys differentiated varieties $\left(y_{\tilde{j} t}\right)$ and sells a homogeneous final good $\left(y_{t}\right)$ at price $P_{t}$.

The competitive retail sector

The competitive retail aggregator maximises $\left\{P_{t}\left(\int y_{\widetilde{j t}}^{(1-1 / \theta)} d_{\widetilde{j}}\right)^{\frac{\theta}{\theta-1}}-\int P_{\widetilde{j} t} y_{\widetilde{j t}} d_{\tilde{j}}\right\}$. It buys differentiated goods from firms in the intermediate sector and sells a homogeneous final good $y_{t}$ at price $P_{t}$. Each variety $y_{\widetilde{j} t}$ is purchased at a price $P_{\widetilde{j} t}$, where $\theta>1$ is a parameter that can be expressed in terms of the elasticity of substitution between intermediate goods $\varkappa \geq 0$, as $\theta=(1+\varkappa) / \varkappa$. The first-order condition gives the following expression for the demand of each variety:

$$
y_{\widetilde{j t}}=\left(\frac{P_{\widetilde{j} t}}{P_{t}}\right)^{-\theta} y_{t}
$$

Also from the zero profit condition of the aggregator, the retailer's price is given by:

$$
P_{t}=\left[\int_{0}^{1}\left(P_{\tilde{j} t}\right)^{1-\theta} d \hat{j}^{\frac{1}{1-\theta}}\right.
$$

\section{The monopolistically competitive intermediate sector}

The monopolistically competitive intermediate sector comprises $\widetilde{j}=1, \ldots \widetilde{J}$ firms each of which buys the production of competitive wholesale firms at a common price $P_{t}^{w}$ and sells a differentiated variety $y_{\widetilde{j} t}$ at a price $P_{\widetilde{j} t}$ to the final competitive retailing sector described above. Variety producers stagger prices. Following Calvo (1983), only some firms set their prices optimally each period. Those firms that do not reset their prices optimally at $t$ adjust them according to a simple indexation rule to catch up with lagged inflation. Thus, each period a proportion $\omega$ of firms simply set $P_{\widetilde{j t}}=\left(1+\pi_{t-1}\right)^{\varsigma} P_{\widetilde{j t}-1}$ (with $\varsigma$ representing the degree of indexation and $\pi_{t-1}$ the inflation rate in $t-1$ ). The fraction of firms (of measure $1-\omega)$ that set the optimal price at $t$ seek to maximise the present value of expected profits. There is an entry $\cos t \kappa_{f}$, which ensures that extraordinary profits vanish in imperfectly 
competitive equilibrium.

The solution for this problem combined with (12) gives an expression for the aggregate price level and inflation that depends on the marginal cost, $\widehat{m c}_{t}$, and can be represented in log-linear form as,

$$
\pi_{t}=\gamma^{f} E_{t} \pi_{t+1}+\varrho \widehat{m c}_{t}+\gamma^{b} \pi_{t-1}
$$

where $\gamma^{f}=\frac{\beta^{l}}{1+\varsigma \beta^{l}}, \gamma^{b}=\frac{\varsigma}{1+\varsigma \beta^{l}}$ and $\varrho=\frac{\left(1-\beta^{l} \omega\right)(1-\omega)}{\omega\left(1+\varsigma \beta^{l}\right)}$.

The competitive wholesale sector

The competitive wholesale sector consists of $j=1, \ldots J$ firms each producing a homogeneous good that they sell at the same price $P_{t}^{w}$ to the monopolistically competitive intermediate sector. Firms in this sector carry out the actual production using labour and capital by means of the function

$$
y_{t}=A_{t} k_{t-1}^{1-\alpha}\left(n_{t-1} l_{1 t}\right)^{\alpha}
$$

Factor demands are obtained by solving a standard cost minimisation problem subject to the dynamics of employment,

$$
n_{t}=(1-\sigma) n_{t-1}+\rho_{t}^{f} v_{t}
$$

where $\rho_{t}^{f}$ is the probability that a vacancy will be filled in any given period $t$, which is exogenous from the perspective of the firm and is determined at aggregate level by the following Cobb-Douglas matching function:

$$
\rho_{t}^{w}\left(1-n_{t-1}\right)=\rho_{t}^{f} v_{t}=\chi_{1} v_{t}^{\chi_{2}}\left[\left(1-n_{t-1}\right) l_{2}\right]^{1-\chi_{2}}
$$

The solution to the optimisation program above generates the following first-order conditions for private capital and the number of vacancies

$$
\begin{aligned}
& r_{t}=(1-\alpha) m c_{t+1} \frac{y_{t+1}}{k_{t}} \\
& \frac{\kappa_{v}}{\rho_{t}^{f}}=\beta^{l} E_{t} \frac{\lambda_{1 t+1}^{l}}{\lambda_{1 t}^{l}} \frac{\partial V_{t+1}^{f}}{\partial n_{t}}
\end{aligned}
$$

where the demand for private capital (17) is positively related to its marginal product, which in equilibrium must be equal to the gross return on physical capital. Expression (18) 
reflects that firms choose the number of vacancies in such a way that the marginal recruiting cost per vacancy, $\kappa_{v}$, is equal to the expected present value of holding it $\beta^{l} E_{t} \frac{\lambda_{1 t+1}^{l}}{\lambda_{1 t}^{l}} \rho_{t}^{f} \frac{\partial V_{t+1}}{\partial n_{t+1}}$, where $V^{f}\left(\Omega_{t}^{f}\right)$ represents the maximum expected value of the firm in state $\Omega_{t}^{f}$.

Using the Bellman equation, the marginal value of an additional job in $t$ for a firm $\left(\lambda_{f t}\right)$ is,

$$
\lambda_{f t} \equiv \frac{\partial V_{t}}{\partial n_{t-1}}=\alpha m c_{t} \frac{y_{t}}{n_{t-1}}-w_{t} l_{1 t}+(1-\sigma) \beta^{l} E_{t} \frac{\lambda_{1 t+1}^{l}}{\lambda_{1 t}^{l}} \frac{\partial V_{t+1}^{f}}{\partial n_{t}}
$$

where the marginal contribution of a new job to profits equals the marginal product net of the wage rate, plus the capital value of the new job in $t$, corrected for the probability that the job will continue in the future. Now using (19) one period ahead, we can rewrite condition (18) as:

$$
\frac{\kappa_{v}}{\rho_{t}^{f}}=\beta^{l} E_{t}\left[\frac{\lambda_{1 t+1}^{l}}{\lambda_{1 t}^{l}}\left(\alpha m c_{t+1} \frac{y_{t+1}}{n_{t}}-w_{t+1} l_{1 t+1}+(1-\sigma) \frac{\kappa_{v}}{\rho_{t+1}^{f}}\right)\right]
$$

\subsection{Trade in the labour market: the labour contract}

There are simultaneous flows in and out of the employment state, so an increase (reduction) in the stock of unemployment results from the predominance of job losses (creation) over job creation (losses). Stable unemployment occurs whenever inflows and outflows cancel each other out, i.e.,

$$
\rho_{t}^{f} v_{t}=\rho_{t}^{w}\left(1-n_{t-1}\right)=\chi_{1} v_{t}^{\chi_{2}}\left[\left(1-n_{t-1}\right) l_{2}\right]^{1-\chi_{2}}=\sigma n_{t-1} .
$$

As it takes time and real resources to make profitable contacts, some pure economic rent emerges with each new job, which is equal to the sum of the expected transaction (search) costs the firm and the worker will further incur if they refuse to match. The emergence of such rent gives rise to a bilateral monopoly framework. Once a representative jobseeking worker and vacancy-offering firm match, they negotiate a labour contract in hours and wages. There is risk-sharing at household level and hence consumption within each household type is independent of the employment status. Patient and impatient households delegate the bargaining process with firms to a trade union that maximises the aggregate marginal value of employment for workers $\lambda_{h t}=\left(1-\tau^{b}\right) \frac{\lambda_{h t}^{l}}{\lambda_{1 t}^{l}}+\tau^{b} \frac{\lambda_{h t}^{b}}{\lambda_{1 t}^{b}}$ and distributes employment according to their shares in the working-age population. The terms $\lambda_{h t}^{l} / \lambda_{1 t}^{l}$ and $\lambda_{h t}^{b} / \lambda_{1 t}^{b}$ respectively denote the earning premium (in terms of consumption) of employment over unemployment for a patient and an impatient worker. The implication of this assumption is that all workers receive the same wage, work the same number of 
hours and suffer the same unemployment rates. The Nash bargain process maximises the weighted product of the parties' surpluses from employment, $\left\{\max _{w_{t}, l_{1 t}}\left(\lambda_{h t}\right)^{\lambda^{w}}\left(\lambda_{f t}\right)^{1-\lambda^{w}}\right\}$, where $\lambda^{w} \in[0,1]$ reflects workers' bargaining power. The solution of the Nash maximisation problem gives the optimal real wage and hours worked (Boscá et al., 2011):

$$
\begin{gathered}
w_{t} l_{1 t}=\lambda^{w}\left(\alpha m c_{t} \frac{y_{t}}{n_{t-1}}+\frac{\kappa_{v} v_{t}}{\left(1-n_{t-1}\right)}\right) \\
+\left(1-\lambda^{w}\right)\left[\left(\frac{\left(1-\tau^{b}\right)}{\lambda_{1 t}^{l}}+\frac{\tau^{b}}{\lambda_{1 t}^{b}}\right)\left(\phi_{2} \frac{\left(1-l_{2}\right)^{1-\eta}}{1-\eta}-\phi_{1} \frac{\left(1-l_{1 t}\right)^{1-\eta}}{1-\eta}\right)\right] \\
+\left(1-\lambda^{w}\right)\left(1-\sigma-\rho_{t}^{w}\right) \tau^{b} E_{t} \frac{\lambda_{h t+1}^{b}}{\lambda_{1 t+1}^{b}}\left(\beta^{l} \frac{\lambda_{1 t+1}^{l}}{\lambda_{1 t}^{l}}-\beta^{b} \frac{\lambda_{1 t+1}^{b}}{\lambda_{1 t}^{b}}\right) \\
\alpha m c_{t} \frac{y_{t}}{n_{t-1} l_{1, t}}=\left[\frac{1-\tau^{b}}{\lambda_{1 t}^{l}}+\frac{\tau^{b}}{\lambda_{1 t}^{b}}\right] \phi_{1}\left(1-l_{1 t}\right)^{-\eta}
\end{gathered}
$$

Unlike the Walrasian outcome, the wage prevailing in the search equilibrium is related (although not equal) to the marginal rate of substitution of consumption for leisure and the marginal product of labour, depending on worker bargaining power $\lambda^{w}$. Putting aside the last term on the right-hand side of (22), the wage is a weighted average of the highest feasible wage (i.e., the marginal productivity of labour plus hiring costs per unemployed worker) and the outside option (i.e., the reservation wage as given by the difference between the utility of leisure of an unemployed person and an employed worker). This reservation wage is, in turn, a weighted average of the lowest acceptable wage of both types of workers. They differ in the marginal utility of consumption $\left(\lambda_{1 t}^{l}\right.$ and $\left.\lambda_{1 t}^{b}\right)$. If the marginal utility of consumption is high, the workers are ready to accept a relatively low wage. The third term on the right-hand side of (22) is part of the reservation wage that depends only on the existence of impatient workers and can be interpreted as an inequality term in utility (see Boscá et al, 2011).

Notice that the presence of the financial constraint exerts a direct effect on labour market outcomes. Both the share of impatient households, $\tau^{b}$ and the intensive financial margin, $m^{b}$ (which determines $\lambda_{1 t}^{b}$ ) appear in (22) and (23) shaping the intensive margin in the labour market. This in turn affects the decisions made by firms regarding vacancy posting (20) and employment creation (15). Finally, notice that when $\tau^{b}=0$, all consumers are patient and, therefore, the solutions for the wage rate and hours simplify to the standard ones. 


\subsection{Policy instruments and the accounting identity}

We assume the existence of a central bank in our economy that follows a Taylor's interest rate rule:

$$
1+r_{t}^{n}=\left(1+r_{t-1}^{n}\right)^{r_{R}}\left(\left(1+\pi_{t-1}\right)^{1+r_{\pi}}\left(\frac{y_{t-1}}{\bar{y}}\right)^{r_{y}}\left(1+\bar{r}^{n}\right)\right)^{1-r_{R}}
$$

where $\bar{y}$ and $\bar{r}^{n}$ are steady-state levels of output and interest rate, respectively. The parameter $r_{R}$ captures the extent of interest rate inertia, and $r_{\pi}$ and $r_{y}$ represent the weights given by the central bank to inflation and output objectives.

Government revenues and expenditures each period are made consistent by means of the intertemporal budget constraint

$$
b_{t}=g_{t}+t r h_{t}+\frac{\left(1+r_{t-1}^{n}\right)}{1+\pi_{t}} b_{t-1}
$$

where $t r h_{t}$ stands for lump-sum transfers/taxes. In order to enforce the government's intertemporal budget constraint, the following fiscal policy reaction function is imposed

$$
t r h_{t}=t r h_{t-1}-\psi_{1}\left[\frac{b_{t}}{g d p_{t}}-\overline{\left(\frac{b}{g d p}\right)}\right]-\psi_{2}\left[\frac{b_{t}}{g d p_{t}}-\frac{b_{t-1}}{g d p_{t-1}}\right]
$$

where $\psi_{1}>0$ captures the speed of adjustment from the current ratio towards the desired target $\overline{\left(\frac{b}{g d p}\right)}$. The value of $\psi_{2}>0$ is chosen to ensure a smooth adjustment of current debt towards its steady-state level.

Finally, to close the model, output is defined as the sum of demand components.

$$
y_{t}=A_{t} k_{t-1}^{1-\alpha}\left(n_{t-1} l_{1 t}\right)^{\alpha}=c_{t}+j_{t}\left(1+\frac{\phi}{2}\left(\frac{j_{t}}{k_{t-1}}\right)\right)+g_{t}+\kappa_{v} v_{t}
$$

\subsection{Calibration}

\section{Parameters from previous studies}

The benchmark model is calibrated using standard values in the literature for some parameters and matching some relevant data moments for the US economy. Table 1 summarises the values of the main calibrated parameters. From Iacoviello (2005) we take $\beta^{l}=0.99, \beta^{b}=0.95$ and the share $\tau^{b}$ of impatient borrowers, which amounts to $36 \%$ of the 
total population ${ }^{7}$. We choose slightly lower and higher values than Iacoviello and Neri (2010) for the loan-to-value ratios representing the low and high indebtedness regimes: $m^{b}=0.735$ and $m^{b}=0.985$. We set $\alpha=0.7$, and the depreciation rate of physical capital $\delta=0.025$. The elasticity of matching to vacant posts $\chi_{2}=0.5$ comes from Monacelli et al (2010) and the exogenous transition rate from employment to unemployment, $\sigma=$ 0.15, from Andolfatto (1996) and Cheron and Langot (2004). These authors also provide some average steady-state values, such as the probability of a vacant position becoming a productive job, which is assumed to be $\bar{\rho}^{f}=0.9$, the fraction of time spent working, $\overline{l_{1}}=1 / 3$, and the fraction of time households spend searching $l_{2}=1 / 6$. The long-run employment ratio is computed to be $\bar{n}=0.75$ as in Choi and Rios-Rull (2009). We assume that equilibrium unemployment is socially-efficient (see Hosios, 1990) and hence $\lambda^{w}=0.5$ $=1-\chi_{2}$. We choose $\eta=2$ implying that average individual labour supply elasticity $\left(\eta^{-1}\left(1 / \overline{l_{1}}-1\right)\right)$ is equal to 1 , the same as in Andolfatto (1996). The adjustment costs parameter for productive investment $\phi=5.5$, is taken from QUEST II and the parameters of the New Phillips Curve are also standard in the literature. We set a value of $\theta=6$ for the elasticity of final goods implying a steady-state mark-up of $\frac{\theta}{\theta-1}=1.2$. Hence, the steady-state value for the marginal cost is obtained as $\overline{m c}=\frac{\theta-1}{\theta}$. The probability of not changing prices, $\omega$, is set to 0.75 , meaning that prices change every four quarters on average, whereas we take an intermediate value, $\varsigma=0.4$, for inflation indexation.

\section{Calibrated parameters from steady-state relationships}

We normalise both steady-state output $(\bar{y})$ and real housing prices $(\bar{q})$ to one. Steadystate government expenditure $\bar{g} / \bar{y}$, is set to 17 per cent of output (US Bureau of Economic Analysis data for 2009). We obtain the long-run value for vacancies from (21) $\bar{v}=\sigma \bar{n} / \bar{\rho}^{f}$. Then, we calibrate the ratio of recruiting expenditures to output $\left(\kappa_{v} \bar{v} / \bar{y}\right)$ to represent 0.5 percentage points of output, as in Cheron and Langot (2004) or Choi and Rios-Rull (2009), and very close to the value of 0.44 implied by the calibration of Monacelli et al. (2010). From this ratio we obtain a value of $\kappa_{v}=0.04$ and using the steady-state version of equation (20), we can solve for the wage $(\bar{w})$. The steady-state value of matching flows in the economy equals the flow of jobs that are lost $(\sigma \bar{n})$ and we use the equality $\left(\sigma \bar{n}=\chi_{1} \bar{v}^{\chi_{2}}\left[(1-\bar{n}) l_{2}\right]^{1-\chi_{2}}\right)$ to solve for the scale parameter of the matching function $\chi_{1}=1.56$.

7 A share of about $36 \%$ of constrained consumers in the US economy is consistent with some of the most recent estimations (Bartolomeo et al, 2011 or Kiley, 2010) but lower than the 50\% seminal estimate share by Campbell and Mankiw (1990), the proportion of US households that according to Lusardi et al (2011) can be considered financially fragile (also 50\%), and the 55\% of the consumers that Misra and Surico (2011) show do not behave in a Ricardian manner. 
The long-run value of total factor productivity, $A=1.521$, is calibrated from the production function to obtain the steady-state value of Tobin's q ratio, $\frac{\bar{\lambda}_{2}^{l}}{\bar{\lambda}_{1}^{l}}$. The return on capital $(\bar{r})$ comes from the first-order conditions and the steady-state value for capital stock $(\bar{k})$ from (17). Capital stock, together with the depreciation rate and the adjustment cost parameter, allows us to calculate the value of gross investment for the steady state and, using the aggregate constraint, the level of consumption $\bar{c}$. The steady-state value of the nominal interest rate $\bar{r}^{n}$, is related to the intertemporal discount rate of lenders through the steady-state version of the first-order condition for consumption. The value for the transfers in the steady state $\overline{t r h}$ are such that from the government budget constraint the resulting debt-to-output ratio is 60 per cent on annual terms. In order to compute $\kappa_{f}$, we aggregate the income restriction of both households in the steady state, to obtain

$$
c+j\left(1+\delta \frac{\phi}{2}\right)+g=n w l+r k+\kappa_{f}
$$

Conditional on the ratio of assets of patient households to total output in the steady state, $\gamma_{l}\left(\bar{b}^{l}=\gamma_{l} \bar{y}\right)$, we can obtain the steady-state values of several variables. Equilibrium in the loan market yields $\bar{b}^{b}$, the steady-state level of consumption of borrowers $\bar{c}^{b}$ is derived from the budget constraint and the consumption level of lenders $\bar{c}^{l}$ from the definition of aggregate consumption. The steady-state levels of the marginal utilities of consumption of both types of consumers, $\bar{\lambda}_{1}^{l}$ and $\bar{\lambda}_{1}^{b}$ are obtained from their respective first-order conditions. We can then obtain borrowers' steady-state housing holdings $\bar{x}^{b}$ from (8) and the long-run equilibrium value of the collateral constraint shadow price $\bar{\mu}^{b}$ from (9). This makes it possible to compute the parameter that accounts for the housing share of life-time utility $\phi_{x}$, from the first-order condition related to housing in borrowers' optimisation program. The value of the parameter $\phi_{x}$ enables us to compute the steadystate holdings of housing for lenders $\bar{x}^{l}$, from their housing first-order condition, and the fixed stock of real estate in the economy $X$, from the equilibrium condition in the housing market. Notice that the values we obtain for $\phi_{x}$ and $X$ depend on the value we assign to the ratio of assets of patient households in the steady state to total output $\gamma_{l}$. In order to produce a sensible calibration of this parameter and the steady-state level of the variables, we follow Iacoviello (2005) and choose a value for $\gamma_{l}$, such that the total stock of housing over yearly output is 140 per cent. The resulting value for $\phi_{x}$ is 0.10 .

As regards preference parameters in the household utility function, $\phi_{1}=1.595$ is calculated from the steady-state version of expression (23). A system of three equations implying the steady state of expressions (6) (10) and (22) is solved for $\phi_{2}, \bar{\lambda}_{h}^{b}$ and $\bar{\lambda}_{h}^{l}$. The resulting value for $\phi_{2}$ is 1.043. Therefore the calibrated values for $\phi_{1}$ and $\phi_{2}$ are similar to those in Andolfatto (1996) and other related research in the literature. Such values imply 
that the value for leisure imputed by an employed worker is well above that imputed by an unemployed worker.

\section{Shocks and policy rule parameters}

Finally the parameters of the policy rules are standard. The response of the interest rate to inflation is $r_{\pi}=0.27$ and the autorregressive term of the rule is $r_{R}=0.73$ (Iacoviello, 2005). In the fiscal rule, the rate of change of transfers reacts negatively to the current deviation of the debt-to-GDP ratio from its target $\left(\psi_{1}=0.01\right)$ and to the rate of change of this ratio $\left(\psi_{2}=0.2\right)$. Finally, the government expenditure shock persistence $\rho_{g}$ is equal to 0.75, as in Brückner and Pappa (2010).

\section{Results}

\subsection{Fiscal policy in models with financially restricted consumers}

In this subsection we assess the relevance of private debt on the dynamic effect of government spending shocks by comparing two otherwise identical models that only differ in the composition of the population: a basic search model with homogeneous consumers ${ }^{8}$ versus an alternative that also features search frictions plus a proportion of indebted consumers. In our benchmark calibration we assume that impatient borrowers amount to $36 \%$ of the total population and that they can borrow up to $98.5 \%$ of the value of their collateral. Both models feature price rigidity that lasts for four quarters. We present impulse-response functions to a (one per cent of GDP) transitory public expenditure shock of some key macroeconomic variables: output, consumption, private debt, housing prices, unemployment and vacancies ${ }^{9}$.

The results are depicted in Figure 4. The labour market responses are broadly consistent with the empirical evidence presented in the second section and very similar in both models. The output response to the public consumption shock is positive in both models. However, the expansionary effect varies substantially, ranging from an impact multiplier of approximately 0.8 points in the basic search model with Ricardian consumers to a significantly higher value of 1.2 in an economy with credit constrained individuals. These differences in output multipliers are explained by the different responses of con-

8 Our benchmark model with impatient consumers that are credit constrained can be transformed into a standard search and matching model with homogeneous consumers by setting $\tau^{b}=0$.

9 In this paper we do not assess other dynamic properties of the model. In Andrés et al (2013) we conduct an extensive analysis of a similar model subject to technology shocks and find that the proposed structure matches the data moments of most labour market variables, both before and after the mortgage market deregulation in the $80 \mathrm{~s}$. 

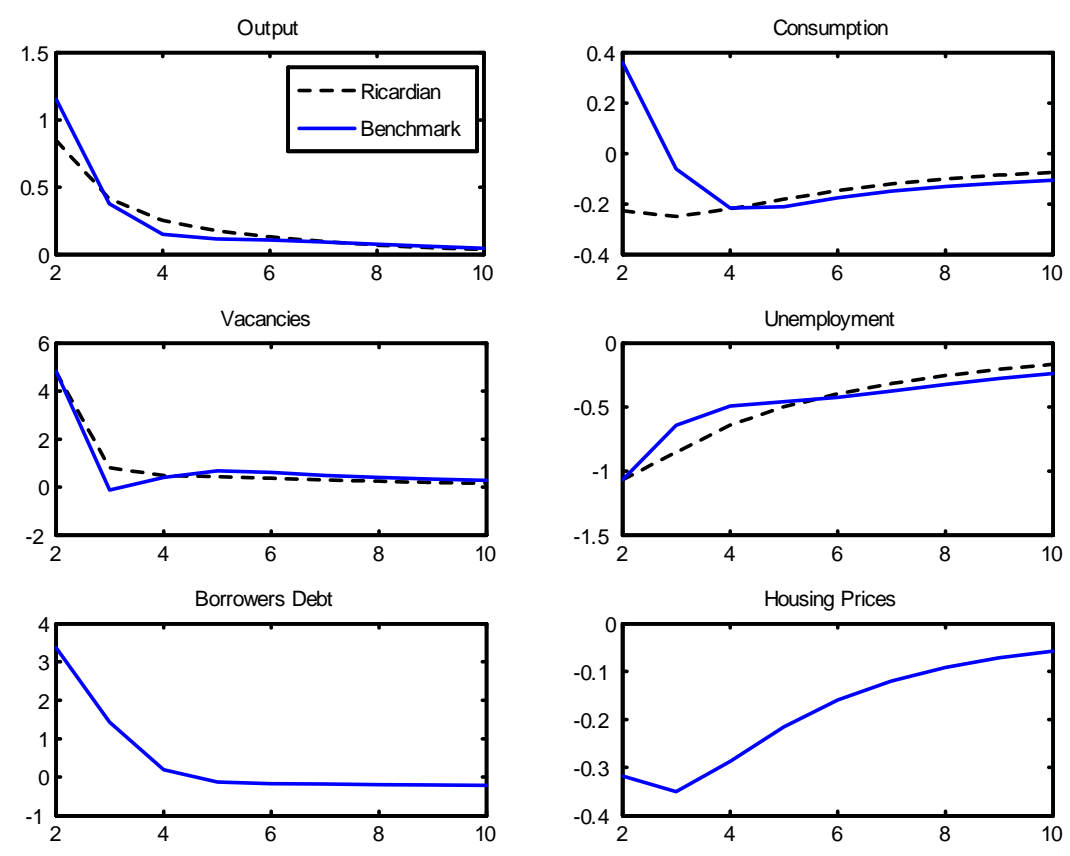

Figure 4: Effects of a transitory public consumption shock: benchmark model and model with Ricardian consumers.

sumption. In the standard search model, the consumption response to the fiscal shock is negative (around -0.2 per cent), while in the model augmented with impatient consumers it is positive (consumption records approximately 0.4 points of crowding-in on impact).

In the basic search model consumption falls on impact due to a negative wealth effect caused by the expectation of future higher taxes and real interest rates as well as lower asset prices. The response of consumption in the model with indebted households is a combination of a negative wealth effect for lenders that reduce their consumption by $-0.33 \%$, and significant current income and collateral effects for impatient households that push their consumption upwards by $2.3 \%$ (not shown in the graph). A closer look at the main drivers of consumption reveals that both hours per worker and the real wage (as well as employment) rise significantly in response to the shock inducing a strong response of current disposable income $\left(w_{t} l_{1 t} n_{t-1}\right)$; this effect is more than offset by the negative wealth effect for lenders that is particularly strong in this case due to the sharp fall in housing prices, which is consistent with our VAR evidence as well as with other results in the literature. In the case of borrowers, the rise in disposable income is reinforced 
by the improvement in collateral $\left(m^{b} E_{t}\left(\frac{q_{t+1}\left(1+\pi_{t+1}\right) x_{t}^{b}}{1+r_{t}^{n}}\right)\right)$, which facilitates their access to credit. This is the reason why financial market participation by borrowers and the presence of private debt strengthen the impact of fiscal policy and make it possible to obtain a Keynesian (higher than one) output multiplier for government expenditure and a positive response of aggregate private consumption. This result is related to the one obtained by Eggertsson and Krugman (2012).

The improvement in the collateral that stems from the fiscal shock is critical to the response of consumption, allowing impatient households to increase their consumption through credit. However, this result might not be of immediate policy relevance since access to consumer credit and mortgages has become more difficult after the financial crisis. The credit crunch has surely reduced the intensive margin for borrowers in the financial market and quite likely the extensive margin as well. Thus, it is worth investigating the impact of this deterioration in financial market conditions on the value of the multiplier.

\subsection{Fiscal policy and private indebtedness}

We now turn our attention to studying the impact of the degree of private indebtedness on the magnitude of fiscal multipliers. Figure 5 depicts the impact fiscal multipliers of our variables of interest as a function of the share of borrowers $\left(\tau^{b}\right)$ and for two different values of the loan-to-value ratio (a low $m^{b}=0.735$ and a high $m^{b}=0.985$ ). These parametric changes in the intensive $\left(m^{b}\right)$ and extensive $\left(\tau^{b}\right)$ margins capture variations in the amount of household indebtedness in the economy ${ }^{10}$. We define the fiscal multiplier on a variable $x\left(\varrho_{x}\right)$ as the ratio between the initial change in the variable from its steady state $\dot{x}_{0}$, and the initial variation of government spending $\dot{g}_{0}$, that is $\varrho_{x}=\frac{\dot{x}_{0}}{\dot{g}_{0}}$.

Figure 5 shows that the fiscal multipliers to a transitory government expenditure shock are very sensitive to the degree of private indebtedness in the economy. When the borrowing capacity of borrowers is high (high loan-to-value ratio) the output multiplier (first column, second row in the figure) is less than one only if the share of borrowers in the population is very low (less than 25 per cent). However, increasing the share of restricted consumers makes the output multiplier grow steadily to values around 1.75 when half of the population is subject to borrowing constraints. On the contrary, if the loan-to-value ratio is low $\left(m^{b}=0.735\right)$, the impact output multiplier is always less than one, regardless of the share of borrowers in the economy. Jointly with the results of the previous subsection,

10 The fiscal multiplier also depends on other characteristics of the economy that interact with the magnitude of the financial friction. Here we stick to the baseline calibration of parameters other than $m^{b}$ and $\tau^{b}$, but we have studied two such features that have received special attention in the literature, namely, the effect of the degree of price stickiness on the one hand, and the effect of the persistence of the shock, which is a key policy parameter, on the other. We find that output (employment) multipliers decrease (increase) markedly with the degree of shock persistence and increase with the degree of price stickiness. These results are available upon request. 

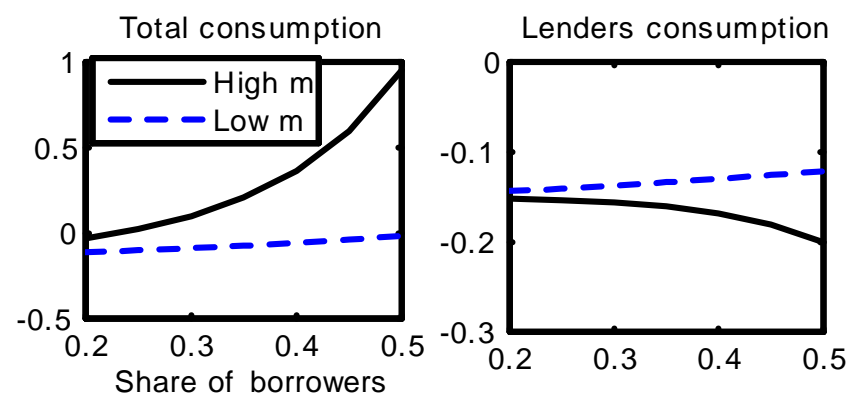

Borrowers consumption

Output
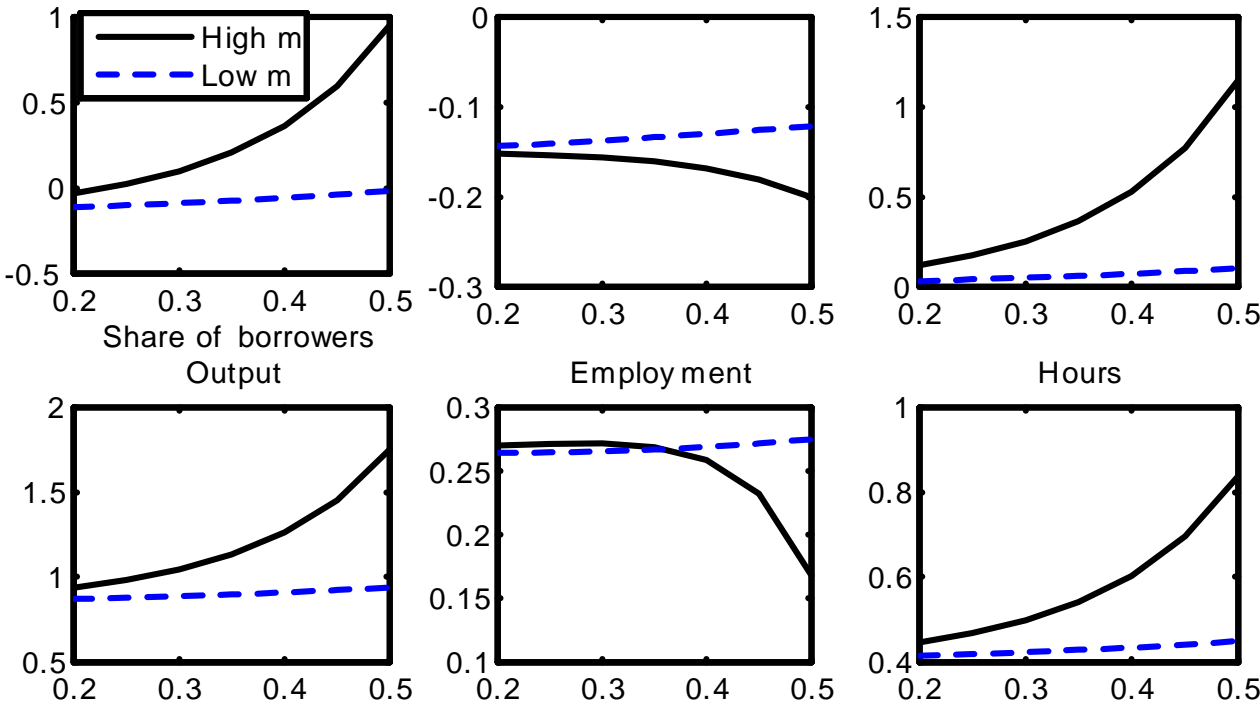

Hours
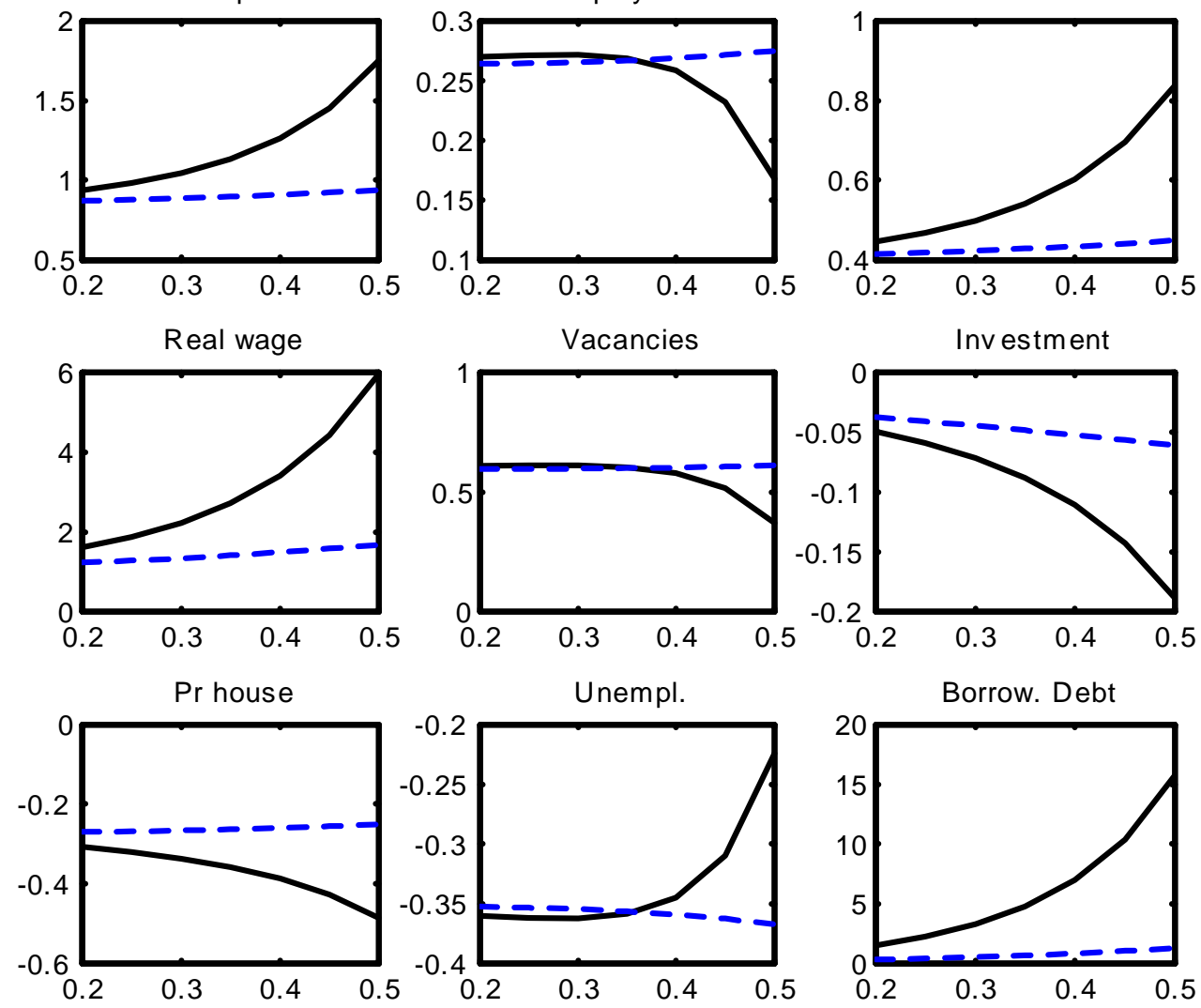

Figure 5: Impact multiplier as a function of the share of borrowers. 
the pattern displayed in Figure 5 indicates that the presence of private debt enhances the impact of fiscal policy, but that this augmented effect of fiscal policy depends critically on the size of $m^{b}$ and $\tau^{b}$. In particular, there seems to be a value of the loan-to-value ratio below which fiscal multipliers are the same size as in a standard search model without private debt. In this case, the response of borrowers' consumption is weaker because they cannot materialise the improvement in their collateral due to the low level of $m^{b}$.

In order to gain further insight into this result we may look at the determinants of borrowers' consumption: current labour and net worth (29), defined as the value of households' asset holdings net of debt ${ }^{11}$. The consumption function of impatient households (28) can be approximated by:

$$
c_{t}^{b} \approx \Theta\left(w_{t} l_{1 t} n_{t-1}^{b}+n w_{t}\right)
$$

where

$$
n w_{t}=\left[q_{t} x_{t-1}^{b}-\frac{\left(1+r_{t-1}^{n}\right) b_{t-1}^{b}}{\left(1+\pi_{t}\right)}\right] .
$$

The reaction of $n w_{t}$ to the fiscal shock is not straightforward. The rise in $\pi_{t}$ above expected inflation reduces the cost of servicing the debt, whereas the negative response of housing prices $\left(q_{t}\right)$ pushes net worth down. In the model, the latter effect dominates the former and $n w_{t}$ falls on impact ${ }^{12}$. But the importance of this "negative net worth effect" depends critically on the loan-to-value ratio itself. When $m^{b}$ is high borrowers accumulate a lot of wealth (houses), but they are also highly leveraged; in fact, the steady-state net worth $\left(n w=q x^{b}\left(1-m^{b}\right)\right)$ tends to zero as $m^{b}$ approaches 1 . Thus, for consumers who acquire most of their assets on credit, the reaction of $n w_{t}$ is of lesser importance. Less indebted consumers on the contrary hold less assets but higher net worth, as a substantial fraction of their real estate is purchased with current income; hence a negative reaction on behalf of this variable has a greater impact, dragging their consumption down and partially offsetting the increase in current labour income.

Furthermore, the impact reaction of current labour income $\left(w_{t} l_{1 t} n_{t-1}^{b}\right)$ is also stronger when there is easy access to credit. With high $m^{b}$ the presence of borrowers whose consumption increases after the financial shock strengthens workers' bargaining power in

11 Equation (28) is as an approximation that holds exactly under linear preferences on labour supply and a frictionless labour market. In the presence of search and matching frictions the marginal propensity to consume $(\Theta)$ is not constant, but varies over the cycle (the demonstration is available upon request).

12 Thus borrowers also experience a negative wealth effect, although unlike that of lenders, associated to the fall in the present value of expected disposable income over their entire lifetime (or the value of their assets), in this case it is caused by the differential response of assets and liabilities in their balance sheet. 

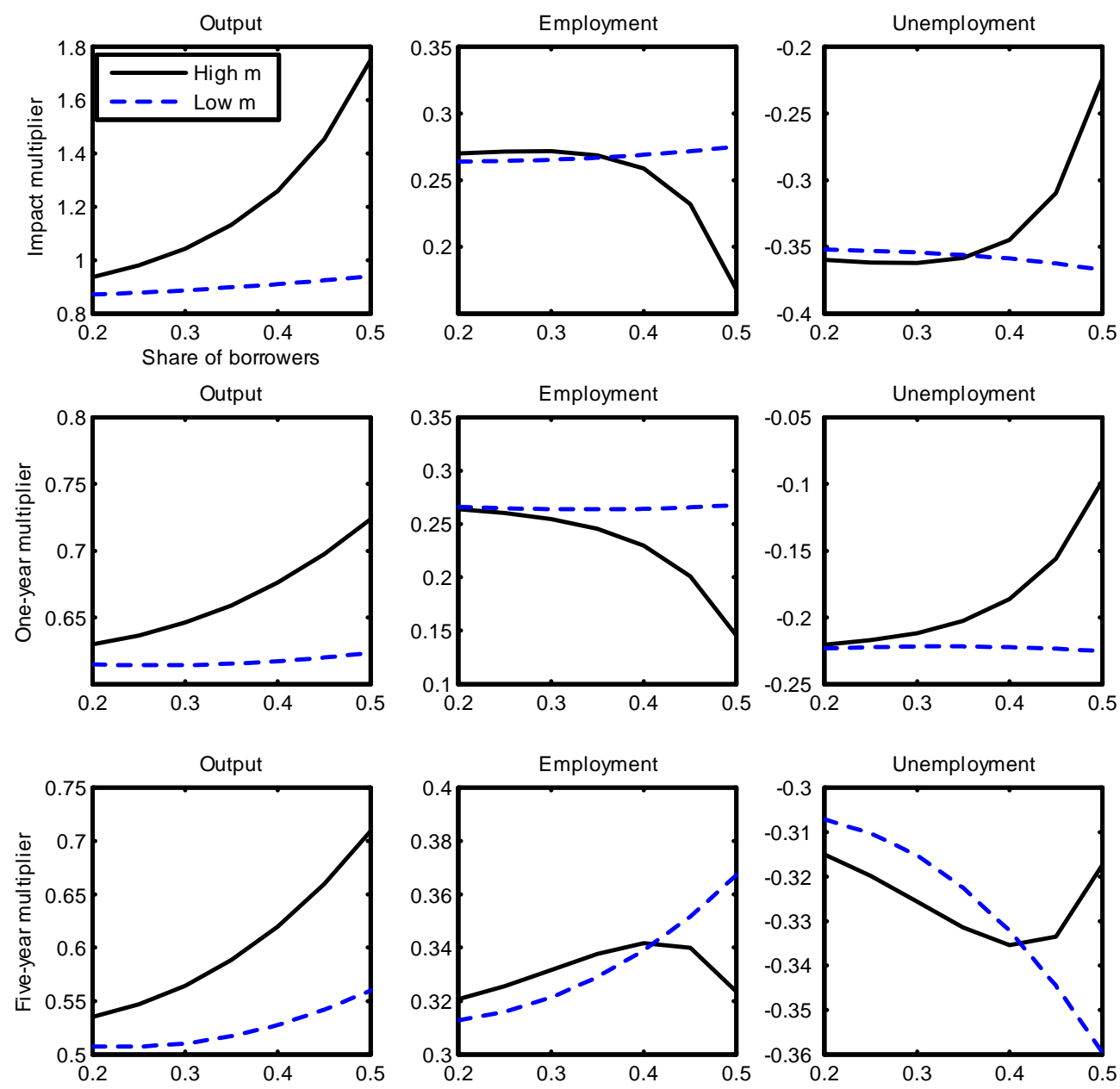

Figure 6: Present value multipliers (impact, one-year and five-year multipliers) 
negotiations. The term $\left[\left(\frac{\left(1-\tau^{b}\right)}{\lambda_{1 t}^{l}}+\frac{\tau^{b}}{\lambda_{1 t}^{b}}\right) \ldots\right]$ in the wage equation (22) captures this effect. Lenders' consumption goes down on impact, whereas that of borrowers increases. The increase in lenders' marginal propensity to consume following a government spending shock $\left(\nabla c_{t}^{l} \Rightarrow \Delta \lambda_{1 t}^{l}\right)$ makes them willing to work for a lower wage. The opposite happens to impatient consumers whose consumption has increased $\left(\Delta c_{t}^{b} \Rightarrow \nabla \lambda_{1 t}^{b}\right)$ and push for higher wages. The latter effect augments with $m^{b}$ and $\tau^{b}$, inducing a stronger response of the common wage and labour income $w_{t} l_{1 t} n_{t-1}^{b}$. In fact, $\tau^{b}$ and $m^{b}$ reinforce each other as $\tau^{b}$ is multiplying the inverse of the marginal utility of consumption, $\left(\frac{1}{\lambda_{1 t}^{b}}\right.$ that increases with $\mathrm{m}^{b}$ ) in (22). When the loan-to-value ratio is sufficiently high, an increase in the share of impatient households in the population has a significant effect on the response of aggregate consumption to the shock.

Figure 5 also shows some interesting decoupling between the output and the employment and unemployment multipliers as we move from a high loan-to-value ratio to a lower one. While output multipliers are higher in the former case, (un)employment multipliers are stronger in the latter. The reaction of the real wage and the intensive margin to the shock also helps to explain these patterns. In economies with high $m^{b}$ the strong response of wages and working hours explained above discourages new job openings; hence the reaction of new vacancies and employment is also weak. Conversely, in economies with more difficult access to credit the increase in total working hours takes place mostly through new jobs; as hours increase along the extensive margin, total employment increases leading to a strong unemployment multiplier.

The previous results refer to impact multipliers, which are the most commonly used in the literature. Following Uhlig (2010) we have also checked the sensitivity of our results when we consider the present value fiscal multipliers at four and twenty quarters instead. We define the net present value fiscal multiplier for variable $x$ at date $t$ as

$$
\varrho_{x t}=\frac{\sum_{s=0}^{t}\left(1+r_{t}^{n}\right)^{-s} \dot{x}_{s}}{\sum_{s=0}^{t}\left(1+r_{t}^{n}\right)^{-s} \dot{g}_{s}}
$$

Figure 6 depicts the output, employment and unemployment present value multipliers. Although, in general, these multipliers become smaller as we move forward in time, the results of this exercise withstand the differences found between a high and low indebted economy.

\subsection{Fiscal policy in a credit crunch}

One important policy implication of our results is that fiscal policy becomes less effective 
the tighter the conditions in financial markets. However, this can be related with episodes of different regulations in the financial market or with a deterioration in the financial conditions. In this section we use our model to evaluate the capacity of fiscal policy to affect the economy in a situation where private agents are forced into deleveraging due to a credit crunch. To this end, we endogeneize the loan-to-value ratio as $m_{t}^{b}=\left(1+\varepsilon_{t}^{m}\right) m^{b}$, where $\varepsilon_{t}^{m}$ follows an $\mathrm{AR}(2)$ process $\varepsilon_{t}^{m}=\phi_{1}^{m} \varepsilon_{t-1}^{m}+\phi_{2}^{m} \varepsilon_{t-2}^{m}+v_{t}^{m}$. We set $\phi_{1}^{m}=1.83$ and $\phi_{2}^{m}=-0.836$, and we assume the initial value for $\varepsilon_{t-1}^{m}$ and $\varepsilon_{t-2}^{m}$ is equal to zero. Starting from a high indebtedness capacity in the economy $\left(m^{b}=0.985\right)$ and $v_{t}^{m}=0$, the loanto-value ratio is temporarily reduced according to two different magnitudes of the initial shock. In the first case (the slashed line in 7), we hit the $\operatorname{AR}(2)$ process reducing $v_{t}^{m}$ by a one percentage point of $m^{b}$. This generates a maximum reduction of approximately 4 percentage points of $m^{b}$ after 10 quarters, returning very slowly afterwards to the initial value. We call this shock pattern a situation of moderate credit crunch. In the second case (dotted line in Figure 7), the initial fall in $m^{b}$ amounts to 4 percent, the loan-to-value ratio reaching a minimum value of 0.8 . We call this scenario a severe credit crunch $^{13}$.

In order to isolate the effects of fiscal policy on relevant macroeconomic variables, we run two simulations for each of the two credit crunch scenarios described above. First, we simulate the effects on variables when we add the credit crunch to a (one percent of GDP) positive fiscal shock. We obtain the response of the variables as relative deviations from their steady-state values, $\left(\frac{\dot{x}_{t}}{\bar{x}}\right)^{f, c c}$. The impact effects corresponding to the previous exercise are displayed in columns $2 \mathrm{~B}$ and $2 \mathrm{C}$ in Table 2. Second, we obtain the response in the case of only a credit crunch shock with no fiscal shock, $\left(\frac{\dot{x}_{t}}{\bar{x}}\right)^{c c}$ (see columns 3B and $3 \mathrm{C}$ in Table 2 for the initial impact). The net effect of fiscal policy is then computed as the difference between both responses $\left[\left(\frac{\dot{x}_{t}}{x_{s s}}\right)^{f, c c}-\left(\frac{\dot{x}_{t}}{x_{s s}}\right)^{c c}\right]$. Columns $1 \mathrm{~B}$ and $1 \mathrm{C}$ in Table 2 capture the initial impacts of this net effect, which should be compared with column 1A, representing the net effects of fiscal policy when the credit crunch shock is absent.

In Figure 8 we perform the same comparison for a time span of 10 quarters. The main message stemming from this exercise is that fiscal policy in the presence of a severe credit crunch can still generate positive and significant effects on consumption and output as suggested, for example, in Eggertsson and Krugman (2012). However, the net effects of fiscal policy on these variables do not augment with the intensity of the deleveraging effort in the economy. This is so despite the net effect of government spending on borrowers' debt, house prices and the stock of houses favouring consumption expenditure

13 When the economy sufferers a rapid period of private deleveraging it can easily run into the zero bound for the interest rate. This exercise has been designed so that the nominal interest rate does not hit the zero bound in any of the periods considered. Looking at the interaction between fiscal policy and other shocks in the economy, including a credit crunch, when the interest rate reaches the zero bound is a promising line of research. 


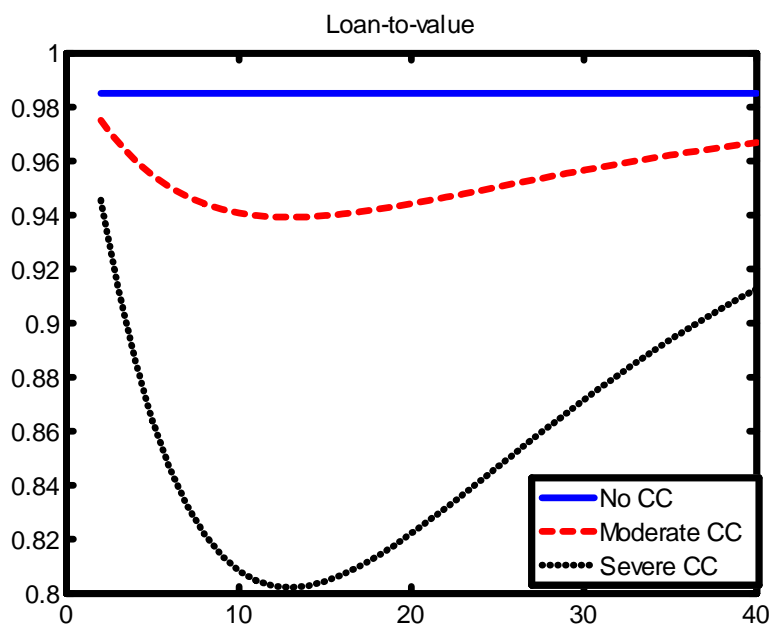

Figure 7: Loan-to-value in three credit crunch (CC) scenarios 
the more intense the credit crunch is. The intuition that public spending impulses can help to prevent a more intense deterioration of the net worth in the presence of a severe contraction of private credit is confirmed by the results in 8 . However, this is insufficient to ensure a stronger response from borrower consumption and output due to the reaction of labour income and especially real wages and hours worked. The net multiplier is, if anything, somewhat smaller the worse the deterioration of credit conditions in the economy. Interestingly, the extensive margin of employment reacts more positively to the fiscal shock in a severe the credit crunch. This is so because fiscal policy does not affect real wages as much in this case, which in turn moderates the (negative) impact on vacancy posting. Hence, although the differential output effect of fiscal stimuli in the event of a sharp credit contraction does not show up in this model, this policy can play a more important role in sustaining employment in a creditless slump.

TABLE 2 - IMPACT EFFECTS OF FISCAL POLICY UNDER A CREDIT CRUNCH

\begin{tabular}{lc|ccc|ccc}
\hline \hline & No Credit Crunch & \multicolumn{3}{|c|}{ Moderate Credit Crunch } & \multicolumn{3}{c}{ Severe Credit Crunch } \\
\hline Variable & $(1 \mathrm{~A})$ & $(1 \mathrm{~B})$ & $(2 \mathrm{~B})$ & $(3 \mathrm{~B})$ & $(1 \mathrm{C})$ & $(2 \mathrm{C})$ & $(3 \mathrm{C})$ \\
\hline Consumption & 1.13 & 0.95 & -3.37 & -4.32 & 0.65 & -13.84 & -14.49 \\
Output & 1.57 & 1.48 & -0.74 & -2.22 & 1.33 & -6.18 & -7.51 \\
Total Hours $(*)$ & 2.29 & 2.25 & 0.21 & -2.05 & 2.18 & -5.17 & -7.35 \\
Real Wage & 2.14 & 1.78 & -3.23 & -5.01 & 1.12 & -14.91 & -16.03 \\
House Prices & -0.39 & -0.34 & -1.02 & -0.68 & -0.26 & -2.98 & -2.72 \\
Real Interest $(\mathrm{bp})$ & 3.50 & 7.74 & -11.17 & -12.75 & 19.13 & -40.31 & -38.86 \\
Inflation (bp) & 30.25 & 26.68 & -27.81 & -54.49 & 20.75 & -149.9 & -170.6 \\
Borrow. Debt & -0.21 & -0.13 & -3.62 & -3.49 & 0.04 & -14.22 & -14.26 \\
\hline \hline
\end{tabular}

(1A), (1B) and (1C): Net Effects of Fiscal Shock.

(2B) and (2C): Fiscal shock plus Credit Crunch shock.

(3B) and (3C): Credit Crunch shock.

${ }^{*}$ ) The reduction in total hours is accompanied by a small positive reaction of employment after the credit crunch.

\subsection{Indebted households versus Rule of Thumb consumers}

The results in previous subsections seem at odds with the widespread view that the presence of hand-to-mouth (RoT) consumers, with a marginal propensity to consume equal to 1, is essential to obtain high fiscal multipliers (Galí et al., 2007), as these consumers can be considered constrained by an extreme form of financial market (non) participation (i.e. a limiting case where $m^{b}=0$ ). In order to address this apparent contradiction, in Figure 9 we compare the impulse-responses to a (one per cent of GDP) transitory public expenditure shock in our benchmark model with those in an alternative one with the same calibration in which the share of impatient consumers (0.36) is now substituted out by RoT consumers. As is usual in the literature, RoT agents also differ from our constrained households in that 

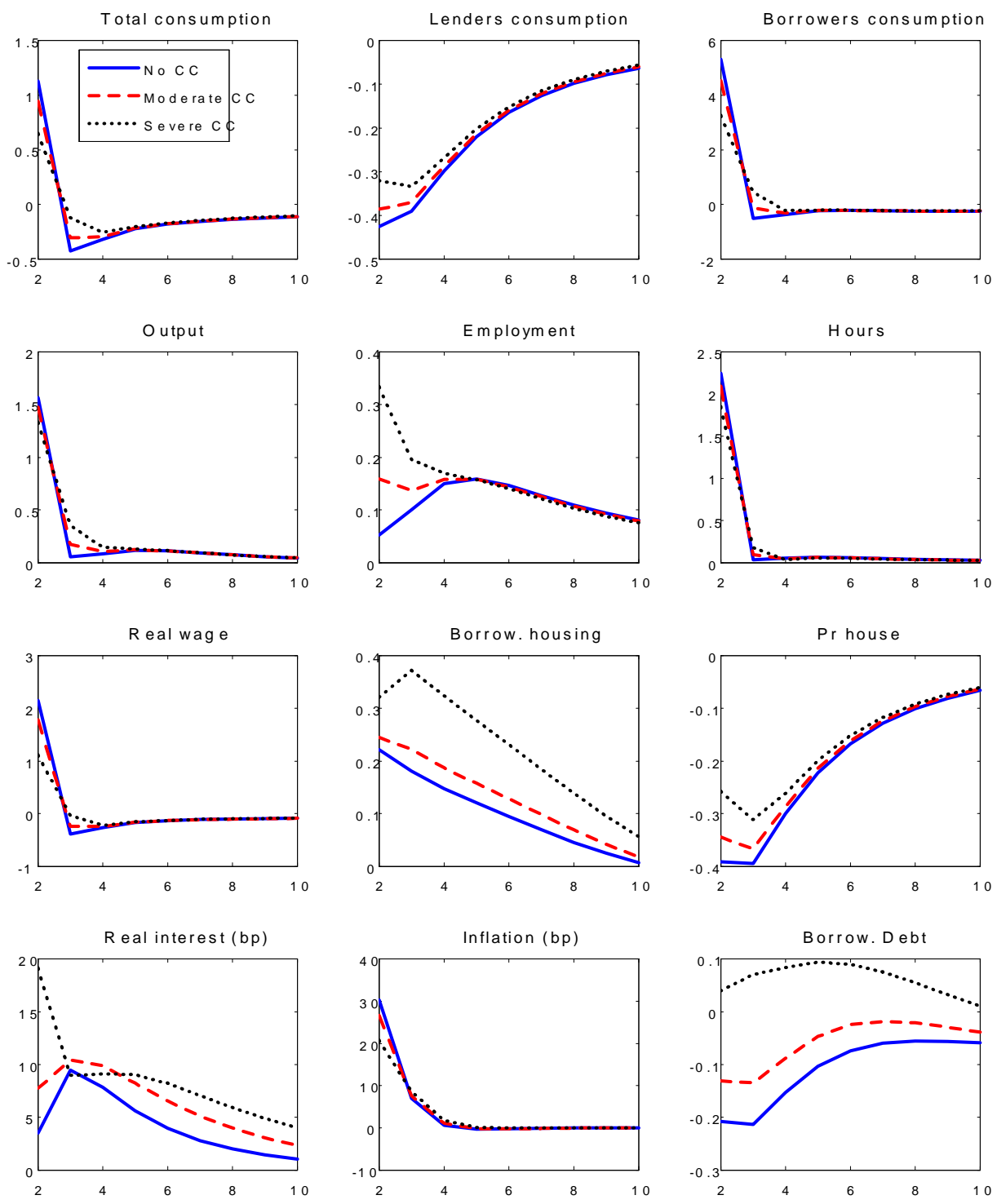

Figure 8: Net effects of fiscal policy under a credit crunch 
they do not hold any assets (housing) either ${ }^{14}$.

Two results from this experiment stand out clearly. First, the impact multiplier is much larger in the RoT model and, second, the pattern of labour market responses is significantly different across models. Differences in the multiplier are explained by the unequal responses of consumption represented by (28) and (30):

$$
c_{t}^{R o T}=w_{t} l_{1 t} n_{t-1}^{R o T}
$$

Compared with the RoT model, the negative response of the net worth of impatient consumers in (28) drags consumption down, dampening the impact of rising current income. Thus, the key to the strong response of consumption in RoT models is the fact that these households consume non durables only and hold no assets, so they do not face the negative net worth effect that borrowers do. In the case of impatient consumers, current income and the net worth move in opposite directions, thus dampening the increase in consumption. As RoT consumers are assumed to hold no assets, this offsetting net worth effect is non-existent.

This also helps to understand why consumption reacts strongly in models with heavily indebted consumers who hold no assets (i.e. those who borrow just to purchase non durables) as in Eggertsson and Krugman (2012). In such a case, their net worth is always negative $\left(\frac{-\left(1+\pi_{t}\right) b_{t-1}^{b}}{\left(1+r_{t-1}^{n}\right)}\right.$ in our notation in (29)), but decreases in absolute value with the fiscal shock, as inflation erodes the real value of the debt with no parallel effect on the (non-existent) asset side of their balance sheet. However, as discussed in the introduction, more than $80 \%$ of household debt in advanced economies is devoted to investing in real estate, so such a model would miss a relevant determinant of household spending decisions.

This simple RoT model also fails to replicate the observed pattern of responses in the labour market. The strong increase in RoT consumption pushes RoT consumers' marginal utility of consumption down, which accordingly strengthens workers position in the bargaining process and leads to a sharp rise in $w_{t} l_{t}$ (see (22)). Thus, firms reduce vacancy posting and employment and unemployment rises in this model. As we have seen in our empirical section this fact confronts existing empirical evidence.

\section{Conclusions}

Fiscal policy multipliers are small in Neo-Keynesian models with Ricardian households.

14 Eliminating preferences for housing from the utility function $\left(\phi_{x}=0\right)$, setting the temporal discount rate $\beta^{b}=\beta^{l}$ and assuming that a share of households, $\tau^{b}$,consume just their current income converts the benchmark model into a search model with a $\tau^{b}$ share of RoT consumers. 

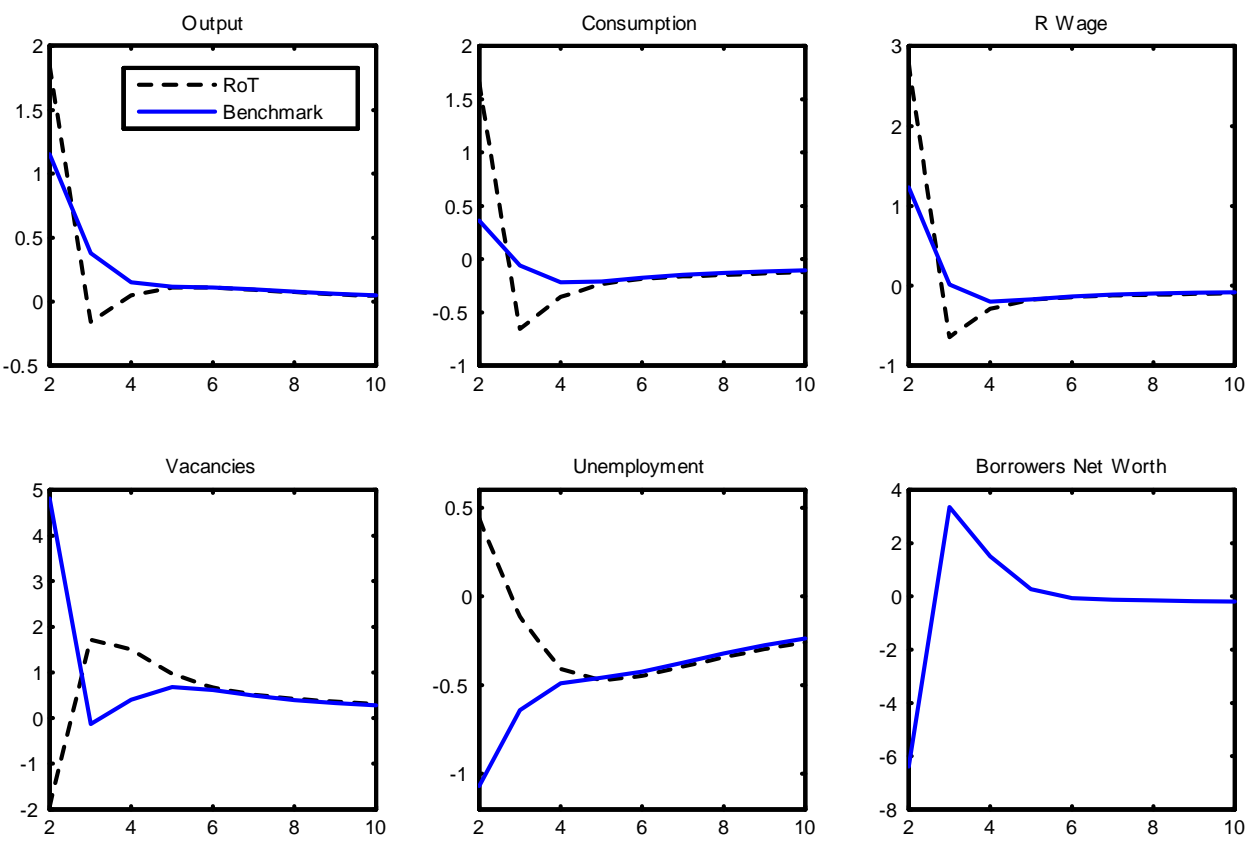

Figure 9: Effects of a transitory public consumption shock: benchmark model and model with RoT consumers. 
The intertemporal substitution mechanism wipes out the expansionary effects of fiscal stimuli depressing not only investment but consumption too. Alternatively, models with consumers that do not participate in the financial market (RoT) are capable of producing strong fiscal responses of output. The size of the multiplier is driven either by the positive impact of a government spending shock on current labour income in the latter model or by the expected negative lifetime income (wealth effect) in the former. But both these models overlook an important feature of modern economies: private debt. If some particularly impatient households have a limited but non-zero borrowing capacity they no longer make their consumption decisions on the basis of their permanent income or their current labour income only. Borrowers take credit to purchase non durable goods and housing so their net worth is neither zero (as in the case of RoTs) nor equal to their total wealth (as in the case of Ricardian households or lenders).

The financial crisis has caught many consumers out with deteriorated balance sheets: high debt, substantial real estate holdings and difficult financial market conditions. As government spending shocks may have complex effects on their net worth (assets and liabilities), it is important to assess how the multipliers are affected by the presence of these types of consumers.

In this paper we augment the search and matching model with the presence of some households that are more impatient than others, who borrow up to a limit given by the expected liquidation value of their housing holdings. The interaction between the consumption decisions of agents with limited access to credit and the process of wage bargaining and vacancy posting produces four main results: (a) the presence of impatient households and private debt helps to generate government spending multipliers greater than 1; (b) as financial conditions worsen and impatient consumers find it more difficult to borrow (i.e. in a credit crunch), the size of the government spending multiplier falls, given that consumers find it more difficult to convert improvements in their collateral into additional borrowing; (c) unlike output multipliers, employment, vacancies and unemployment multipliers are larger when the loan-to-value ratio is low; the presence of an intensive and extensive margin of employment in the model explains why many of the factors that weaken the output response to increases in government spending shocks reinforce the (un)employment multiplier; and (d) the model explains the observed pattern of responses of labour market variables, housing prices and private debt to a fiscal shock reasonably well, outperforming the standard model with RoT (hand-to-mouth) consumers, the predictions of which for the labour market are at odds with the data.

The process of deleveraging of highly indebted industrialised economies is going to shape the spending decisions of both households and firms over forthcoming years. It is critical to understand the effect that this trend may have on the results of traditional policy 
instruments. In particular, fiscal stimuli may interact with variables such as housing prices, borrowing and labour market outcomes in a complex manner. This paper can be viewed as contributing to the incipient line of research that aims to understand these interactions in simple, but yet sufficiently elaborated models, to perform policy simulation exercises. A tentative policy implication that can be drawn from the paper is that, due to the high levels of private indebtedness prevailing at the beginning of the crisis, fiscal multipliers could have been higher than those previously known. However, after some years of deleveraging (credit crunch), the effects of government spending could again have been reduced considerably. The good news according to our analysis is that (un)employment multipliers seem to be reinforced throughout the deleveraging process. 


\section{Appendix 1: Sensitivity analysis of VAR results}
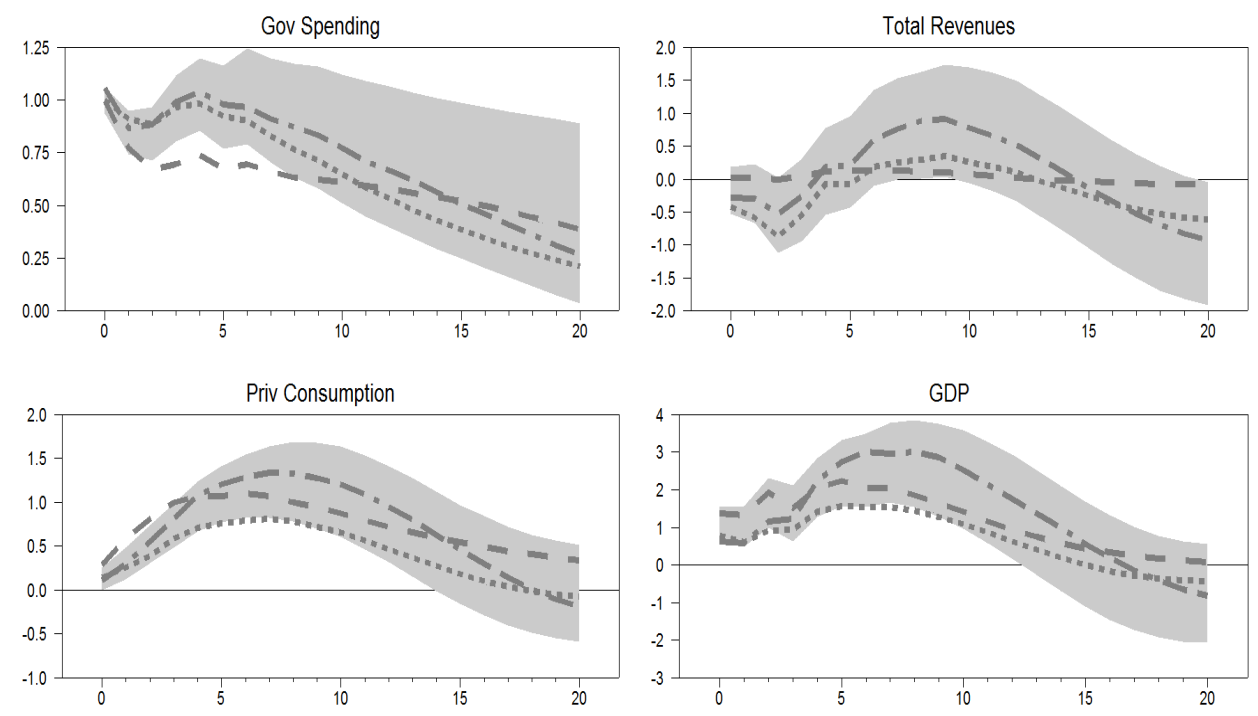

Figure A.1: Impulse responses to a 1\% of GDP increase in government spending.

Notes: (a) Shadow area: confidence interval of the benchmark specification in the main text.

(b) Dotted line: IR of specification without war dummies.

(c) Dashed-dotted line: IR of specification including Debt/GDP variable instead of T-Bill variable.

(d) Dashed line: IR of specification with augmented sample period, 1964:1-2012:4. 

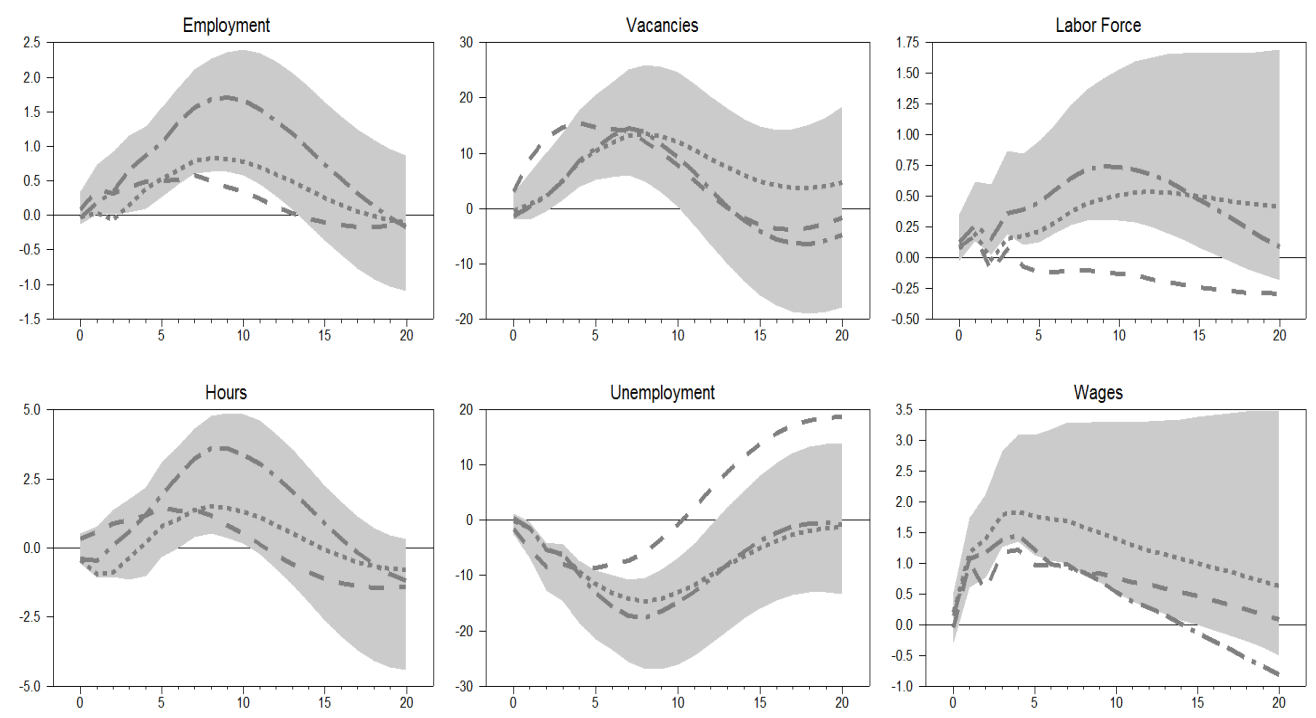

Figure A.2: Impulse responses to a 1\% of GDP increase in government spending.

Notes: (a) Shadow area: confidence interval of the benchmark specification in the main text.

(b) Dotted line: IR of specification without war dummies.

(c) Dashed-dotted line: IR of specification including Debt/GDP variable instead of T-Bill variable.

(d) Dashed line: IR of specification with augmented sample period, 1964:1-2012:4. 

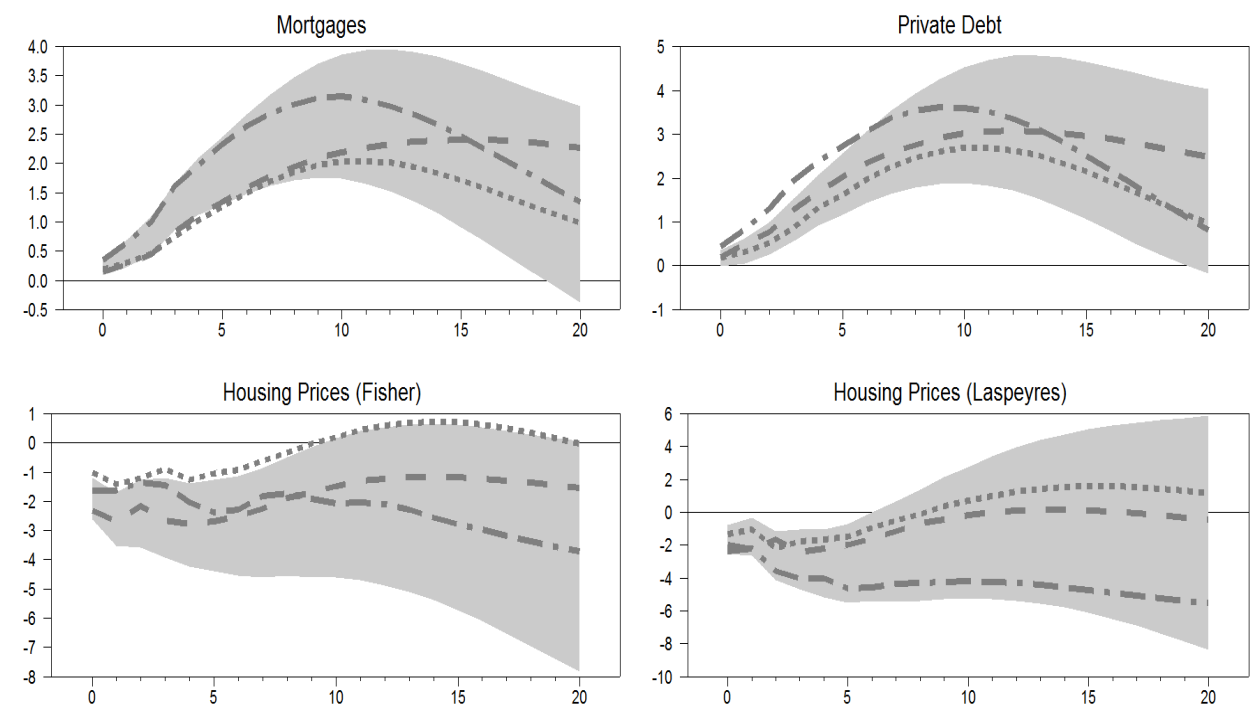

Figure A.3: Impulse responses to a 1\% of GDP increase in government spending.

Notes: (a) Shadow area: confidence interval of the benchmark specification in the main text.

(b) Dotted line: IR of specification without war dummies.

(c) Dashed-dotted line: IR of specification including Debt/GDP variable instead of T-Bill variable.

(d) Dashed line: IR of specification with augmented sample period, 1964:1-2012:4. 


\section{References}

Adam, K., Kuang, P. and A. Marcet (2011). "House Price Booms and the Current Account", NBER Macroeconomics Annual 2011, 26, 77-122.

Agnello, L. and R. M. Sousa (2011): "Can Fiscal Policy Stimulus Boost Economic Recovery?", Document de Trevail $\mathrm{N}^{o} 235$. Banque de France.

Agnello, L. and R. M. Sousa (2012): "Fiscal Policy and Asset Prices", Bulletin of Economic Research, DOI: 10.1111/j.0307-3378.2011.00420.x

Alesina, A. and S. Ardagna (2010): "Large Changes in Fiscal Policy: Taxes versus Spending", in NBER Book Series: Tax Policy and the Economy, Volume 24, Jeffrey R. Brown, editor.

Andolfatto, D. (1996): "Business Cycles and Labor-Market Search", American Economic Review, 86 (1), 112-132.

Andrés, J. and O. Arce (2012): "Banking Competition, Housing Prices and Macroeconomic Stability", The Economic Journal, 122, 1346-1372.

Andrés, J., Boscá, J. E. and J. Ferri (2013): "Household Debt and Labor Market Fluctuations", Journal of Economics Dynamics and Control, 37, 1771-1795.

Ardagna, S. (2009): "Financial Markets' Behavior Around Episodes of Large Changes in the Fiscal Stance", European Economic Review, 53(1), 37-55.

Bartolomeo, G., Rossi, L. and M. Tancioni (2011): "Monetary Policy, Rule-of-Thumb Consumers and External Habits: a G7 Comparison", Applied Economics, 43(21), 2721-2738.

Blanchard, O. and R. Perotti (2002): "An Empirical Characterization of the Dynamic Effects of Changes in Government Spending and Taxes on Output", Quarterly Journal of Economics, 117(4), 13291368.

Boscá, J. E., Doménech, R. and J. Ferri (2011): "Search, Nash Bargaining and Rule of Thumb Consumers", European Economic Review, 55, 927-42.

Brückner M. and E. Pappa (2010): "Fiscal Expansions Affect Unemployment, But They May Increase It", CEPR Discussion Paper No. 7766.

Brückner, M and A. Tuladhar (2014): "Local Government Spending Multipliers and Financial Distress: Evidence from Japanese Prefectures", Economic Journal, forthcoming.

Burnside, C., Eichenbaum, M. and J. Fisher (2004): "Fiscal Shocks and Their Consequences", Journal of Economic Theory, 115(1), 89-117.

Callegari, G. (2007): "Fiscal Policy and Consumption". PhD Thesis. European University Institute.

Calvo, G. (1983): "Staggered Pricing in a Utility Maximizing Framework", Journal of Monetary Economics, 12, 383-96.

Campbell, J. Y. and N. G. Mankiw (1990): "Permanent Income, Current Income, and Consumption", Journal of Business \& Economic Statistics, 8(3), 265-79.

Carrillo, J. A. and C. Poilly (2010): "On the Recovery Path during a Liquidity Trap: Do Financial Frictions Matter for Fiscal Multipliers?", Discussion Papers (IRES - Institut de Recherches Economiques et Sociales) 2010034, Université Catholique de Louvain.

Chéron, A. and F. Langot (2004): "Labor Market Search and Real Business Cycles: Reconciling Nash Bargaining with the Real Wage Dynamics", Review of Economic Dynamics, 7, 476-493. 
Christiano, L., Eichenbaum, M. and S. Rebelo (2011): "When is the government spending multiplier large?", Journal of Political Economy, 119(1), 78-121.

Choi, S. and J. V. Rios-Rull (2009): "Understanding the Dynamics of Labor Share: The Role of Noncompetitive Factor Prices", Annales d'Economie et de Statistique, issue 95-96, 251-277

Cloyne, J. and P. Surico (2014): "Household Debt and the Dynamic Effects of Income Tax Changes", Bank of England Working Paper No. 491, Bank of England.

Cogan, J. F., Cwik, T., Taylor, J. B. and V. Wieland (2010): "New Keynesian versus old Keynesian Government Spending Multipliers", Journal of Economic Dynamics and Control, 34(3), 281-295.

Corsetti, G., Meier, A ad G. Müller (2009): "Fiscal Stimulus with Spending Reversals", The Review of Economics and Statistics, 94, 878-895.

Edelberg, W., Eichenbaum, M. and J. Fisher (1999): "Understanding the Effects of Shocks to Government Purchases", Review of Economic Dynamics, 2, 166-206.

Eggertsson, G. B. and P. Krugman (2012): "Debt, Deleveraging, and the Liquidity-Trap: A Fisher, Minsky, Koo Approach", Quarterly Journal of Economics, 127(3), 1469-1513.

Erceg, C. J. and J. Linde (2013): "Fiscal Consolidation in a Currency Union: Spending Cuts vs. Tax Hikes", Journal of Economic Dynamics and Control, 37, 422-445.

Fatás, A. and I. Mihov (2001): "The Effects of Fiscal Policy on Consumption and Employment: Theory and Evidence", CEPR Discussion Papers 2760.

Favero, C. and F. Giavazzi (2012): "Measuring Tax Multipliers: The Narrative Method in Fiscal VARs", American Economic Journal: Economic Policy, 4(2), 69-94.

Fernández-Villaverde, J. (2010): "Fiscal Policy in a Model With Financial Frictions", American Economic Review: Papers \& Proceedings, 100, 35-40.

Galí, J., Lopez-Salido, J. D. and J. Vallés (2007): "Understanding the Effects of Government Spending on Consumption", Journal of the European Economic Association, 5(1), 227-270.

Giavazzi, F. and M. Pagano (1990): "Can Severe Fiscal Contractions Be Expansionary? Tales of Two Small European Countries", NBER Chapters, in: NBER Macroeconomics Annual, 5, 75-122.

Glick, R. and K. J. Lansing (2010): "Global Household Leverage, House Prices and Consumption", FRBSF Economic Letter, 2010-01. January.

Guerrieri, V. and G. Lorenzoni (2011): "Credit Crises, Precautionary Savings, and the Liquidity Trap", NBER Working Paper 17583.

Hall, R.E. (2011): "The Long Slump", NBER Working Paper 16741.

Hemming, R., Kell, M. and S. Mahfouz (2002): "The Efectiveness of Fiscal Policy in Stimulating Economic Activity - A review of the Literature", IMF Working Paper, WP/02/208.

Iacoviello, M. (2005): "House Prices, Borrowing Constraints, and Monetary Policy in the Business Cycle", American Economic Review, 95(3), 739-764.

Iacoviello, M. and S. Neri (2010): "Housing Market Spillovers: Evidence from an Estimated DSGE Model", American Economic Journal: Macroeconomics, 2(2), 125-64.

International Monetary Fund (2012): "Coping with High Debt and Sluggish Growth". World Economic Outlook. October.

Kaplan, G., Violante, G. L. and J. Weidner (2014): "The Wealthy Hand-to-Mouth", NBER Working 
Paper 20073, National Bureau of Economic Research.

Kiley, M. T. (2010): "Habit Persistence, Nonseparability Between Consumption and Leisure, or Ruleof-Thumb Consumers: Which Accounts for the Predictability of Consumption Growth?", The Review of Economics and Statistics, 92(3), 679-683.

Kiyotaki, N. and J. Moore (1997): "Credit Cycles", Journal of Political Economy, 105(2), 211-248.

Lusardi, A., Schneider, D. and P. Tufano (2011): "Financially Fragile Households: Evidence and Implications", NBER Working Paper 17072.

Mankiw, N.G. (2000): "The Savers-Spenders Theory of Fiscal Policy", American Economic Review. 90(2), 120-125.

Matsuyama, K. (1990): "Residential Investment and the Current Account", Journal of International Economics, 28(1-2), 137-153.

Mian, A. R. and A. Sufi (2010): "Household Leverage and the Recession of 2007 to 2009", NBER Working Paper 15896.

Misra, K. and P. Surico (2011): "Heterogeneous Responses and Aggregate Impact of the 2001 Income Tax Rebates", CEPR Discussion Papers 8306.

Monacelli, T. (2009): "New Keynesian models, durable goods, and collateral constraints", Journal of Monetary Economics, 56, 242-254.

Monacelli, T., Perotti, R. and A. Trigari (2010): "Unemployment Fiscal Multipliers", Journal of Monetary Economics, 57, 531-553.

Monacelli, T., Quadrini, V. and A. Trigari (2011): "Financial Markets and Unemployment", NBER Working Paper 17389.

Mortensen, D T. and C. A. Pissarides (1994): "Job Creation and Job Destruction in the Theory of Unemployment", Review of Economic Studies, 61(3), 397-415.

Parker, J. A., Souleles, N. S., Johnson, D. S. and R. McClelland (2011): "Consumer Spending and the Economic Stimulus Payments of 2008", NBER Working Paper 16684.

Pissarides, C. A. (2011): "Equilibrium in the Labor Market with Search Frictions", American Economic Review, 101, 1092-1105.

Ramey, V. A. and M.D. Shapiro (1998): "Costly capital reallocation and the effects of government spending", Carnegie-Rochester Conference Series on Public Policy, 48(1), 145-194.

Ramey, V. A. (2011a): "Can government purchases stimulate the economy?", Journal of Economic Literature, 49(3), 673-685.

Ramey, V. A. (2011b): "Identifying Government Spending Shocks: it's all in the timing", The Quarterly Journal of Economics, 1-50.

Ravn, M. and S. Simonelli (2008): "Labor Market Dynamics and the Business Cycle: Structural Evidence for the United States", Scandinavian Journal of Economics, 109(4), 743-777.

Roeger W. and J. in 't Veld (2009): "Fiscal Policy with credit constrained households". European Commission, European Economy Economic Paper no. 357.

Romer, C. and J. Bernstein (2009): "The Job Impact of the American Recovery and Reinvestment Plan". Mimeo.

Rossi, B. and S. Zubairy (2011): "What Is the Importance of Monetary and Fiscal Shocks in Explaining 
U.S. Macroeconomic Fluctuations?", Journal of Money, Credit and Banking, 43(6), 1247-1270.

Spilimbergo, A., Symansky, S. and M. Shindler (2009): "Fiscal Multipliers", IMF Staff Position Note, $\mathrm{SPN} / 09 / 11$.

Uhlig, H. (2010): "Some fiscal calculus", American Economic Review, P\&P, 100(2), 30-34.

Woodford, M. (2011): "Simple Analytics of the Government Expenditure Multiplier", American Economic Journal: Macroeconomics, 3(1), 1-35. 


\section{TABle 1 - Parameter VAlues}

\begin{tabular}{|c|c|c|c|}
\hline \multicolumn{4}{|l|}{ Preferences: } \\
\hline Discount factor (lenders), $\beta^{l}$ & 0.99 & Discount factor (borrowers), $\beta^{b}$ & 0.95 \\
\hline Intertemp. labour elasticity of substitution, $\eta$ & 2 & Housing weight in utility, $\phi_{x}$ & 0.10 \\
\hline Leisure preference (empl.), $\phi_{1}$ & 1.595 & Leisure preference (unempl.), $\phi_{2}$ & 1.043 \\
\hline \multicolumn{4}{|l|}{ Household's debt: } \\
\hline Minimum share of impatient consumers, $\tau^{b}$ & 0.20 & Maximum share of impatient consumers, $\tau^{b}$ & 0.50 \\
\hline Low loan-to-value, $m^{b}$ & 0.735 & High loan-to-value, $m^{b}$ & 0.985 \\
\hline \multicolumn{4}{|l|}{ Technology: } \\
\hline labour share in production, $\alpha$ & 0.7 & Depreciation rate of capital, $\delta$ & 0.025 \\
\hline Elasticity of final goods, $\theta$ & 6 & Entry fixed cost, $\kappa_{f}$ & 0.167 \\
\hline \multicolumn{4}{|l|}{ Frictions: } \\
\hline Probability of not changing prices, $\omega$ & 0.75 & Adjustment costs for investment, $\phi$ & 5.5 \\
\hline Inflation indexation, $\varsigma$ & 0.4 & & \\
\hline \multicolumn{4}{|l|}{ Labour market: } \\
\hline Elasticity of matching to vacant posts, $\chi_{2}$ & 0.5 & Transition rate from empl. to unempl., $\sigma$ & 0.15 \\
\hline Workers' bargaining power, $\lambda^{w}$ & 0.5 & Cost of vacancy posting, $\kappa_{v}$ & 0.04 \\
\hline Scale parameter of the matching function, $\chi_{1}$ & 1.56 & & \\
\hline \multicolumn{4}{|l|}{ Policy: } \\
\hline Government expenditure persistence, $\rho_{g}$ & 0.75 & Interest rate smoothing, $r_{R}$ & 0.73 \\
\hline Interest rate reaction to inflation, $r_{\pi}$ & 0.27 & Interest rate reaction to output, $r_{y}$ & 0 \\
\hline
\end{tabular}




\section{ÚLTIMOS DOCUMENTOS DE TRABAJO}

2015-01; "Household Debt and Fiscal Multipliers", J. Andrés, J.E. Boscá y J. Ferri.

2014-21: "Structural Estimation of a Model of School Choices: the Boston Mechanism vs. Its Alternatives", Caterina Calsamiglia, Chao Fu y Maia Güell.

2014-20: "Which club should I attend, Dad?: Targeted socialization and production", Facundo Albornoz, Antonio Cabrales y Esther Hauk.

2014-19: "The Informational Content of Surnames, the Evolution of Intergenerational Mobility and Assortative Mating", Maia Güell, José V. Rodríguez Mora y Chris Telmer.

2014-18: "Risk-sharing and contagion in networks", Antonio Cabrales, Piero Gottardi y Fernando VegaRedondo.

2014-17: "A simple model of aggregate pension expenditure", Ángel de la Fuente.

2014-16: "The economic evaluation of infrastructure investment. Some inescapable tradeoffs", Ginés de Rus.

2014-15: "Cross-country data on the quantity of schooling: a selective survey and some quality measures", Ángel de la Fuente y Rafael Doménech.

2014-14: "Educational Attainmet in the OECD, 1960-2010, (version 3.1)", Ángel de la Fuente y Rafael Doménech.

2014-13: "The Systematic Component of Monetary Policy in SVARs: An Agnostic Identification Procedure", Jonas E. Arias, Dario Caldara y Juan F. Rubio-Ramírez.

2014-12: "Reforming the U.S. Social Security system accounting for employment uncertainty", Hugo Benítez-Silva, J. Ignacio García-Pérez y Sergi Jiménez-Martín.

2014-11: "Estimating Dynamic Equilibrium Models with Stochastic Volatility", Jesús Fernández-Villaverde, Pablo Guerrón-Quintana y Juan F. Rubio-Ramírez.

2014-10: "Efficiency and Endogenous Fertility", Mikel Pérez-Nievas, J. Ignacio Conde-Ruiz y Eduardo L. Giménez.

2014-09: "The Role of Global Value Chains during the Crisis: Evidence from Spanish and European Firms", Aranzazu Crespo y Marcel Jansen.

2014-08: "Can Fixed-Term Contracts Put Low Skilled Youth on a Better Career Path? Evidence from Spain", J. Ignacio García Pérez, Ioana Marinescu y Judit Vall Castello.

2014-07: "Gender Peer Effects in School, a Birth Cohort Approach", Antonio Ciccone y Walter GarciaFontes.

2014-06: "Delaying the Normal and Early Retirement Ages in Spain: Behavioural and Welfare Consequences for Employed and Unemployed Workers", Alfonso R. Sánchez, J. Ignacio García-Pérez y Sergi Jiménez-Martín.

2014-05: "Immigrant Selection over the Business Cycle: The Spanish Boom and the Great Recession, Jesús Fernández-Huertas Moraga.

2014-04: "The Incentive Effects of Minimum Pensions: extended version", Sergi Jiménez-Martín.

2014-03: "A Practitioners' Guide to Gravity Models of International Migration", Michel Beine, Simone Bertoli y Jesús Fernández-Huertas Moraga.

2014-02: "L'auberge Espagnole y el Apartamento Francés: los Determinantes del Aprendizaje del Francés en España", Brindusa Anghel y Maia Güell.

2014-01: "Temporary Intergenerational Mobility and the Informational Content of Surnames" Maia Güell, José V. Rodríguez Mora y Christopher I. Telmer.

2013-25: "Informal Care and Intergenerational Transfers in European Countries", Sergi Jiménez-Martín y Cristina Vilaplana Prieto.

2013-24: "Inference Based on SVARs Identied with Sign and Zero Restrictions: Theory and Applications", Jonas E. Arias, Juan F. Rubio-Ramírez y Daniel F. Waggoner.

2013-23: "Estimating Dynamic Equilibrium Models with Stochastic Volatility", Jesús Fernández-Villaverde, Pablo Guerrón-Quintana y Juan F. Rubio-Ramírez.

2013-22: "Perturbation Methods for Markov-Switching DSGE Models", Andrew Foerster, Juan RubioRamirez, Dan Waggoner y Tao Zha.

2013-21: "Do Spanish informal caregivers come to the rescue of dependent people with formal care unmet needs?", Sergi Jiménez-Martín y Cristina Vilaplana Prieto.

2013-20: "When Credit Dries Up: Job Losses in the Great Recession", Samuel Bentolila, Marcel Jansen, Gabriel Jiménez y Sonia Ruano.

2013-19: "Efectos de género en las escuelas, un enfoque basado en cohortes de edad", Antonio Ciccone y Walter Garcia-Fontes.

2013-18: "Oil Price Shocks, Income, and Democracy", Markus Brückner, Antonio Ciccone y Andrea Tesei. 2013-17: "Rainfall Risk and Religious Membership in the Late Nineteenth-Century US", Philipp Ager y Antonio Ciccone.

2013-16: "Immigration in Europe: Trends, Policies and Empirical Evidence", Sara de la Rica, Albrecht Glitz y Francesc Ortega.

2013-15: "The impact of family-friendly policies on the labor market: Evidence from Spain and Austria", Sara de la Rica y Lucía Gorjón García.

2013-14: "Gender Gaps in Performance Pay: New Evidence from Spain", Sara de la Rica, Juan J. Dolado y Raquel Vegas. 